\title{
Final Report for the Reduction of Chrome (VI) to Chrome (III) in the Secondary Waste Stream of the Effluent Treatment Facility
}

\author{
J. B. Duncan \\ M. D. Guthrie \\ CH2M HILL Hanford Group, Inc \\ Fluor Hanford, Inc \\ Rıchland, WA 99352 \\ U.S Department of Energy Contract DE-AC27-99RL14047

$\begin{array}{lll}\text { EDT/ECN } & \text { DRF } & \text { UC } \\ \text { Cost Center } & 74 \mathrm{~A} 10 & \text { Charge Code } \\ \text { B\&R Code } & & \text { Total Pages }\end{array}$

Key Words Chrome (VI), Chrome (III), test, ETF, TCLP, secondary, waste, stream, simulant electrochemical corrosion scans, chrome reductant testıng, synthetıc, groundwater, brine

\begin{abstract}
This report documents the laboratory results of RPP-PLAN-35958, Test Plan for the Effluent Treatment Facility to Reduce Chrome (VI) to Chrome (III) in the Secondary Waste Stream With the exception of the electrochemical corrosion scans, all work was carried out at the Center for Laboratory Science (CLS) located at the Columbia Basin College This document summarizes the work carried out at CLS and includes the electrochemical scans and associated corrosion rates for 304 and $316 \mathrm{~L}$ stainless steel
\end{abstract}

TRADEMARK DISCLAIMER Reference herein to any specific commercial product, process, or service by trade name, trademark, manufacturer, or otherwise, does not necessarily constitute or imply its endorsement, recommendation, or favoring by the United States Government or any agency thereof or its contractors or subcontractors

Printed in the United States of America To obtain coples of this document, contact Document Control Services, P O Box 950, Mallstop H6-08, Richland WA 99352, Phone (509) 372-2420, Fax (509) 376-4989

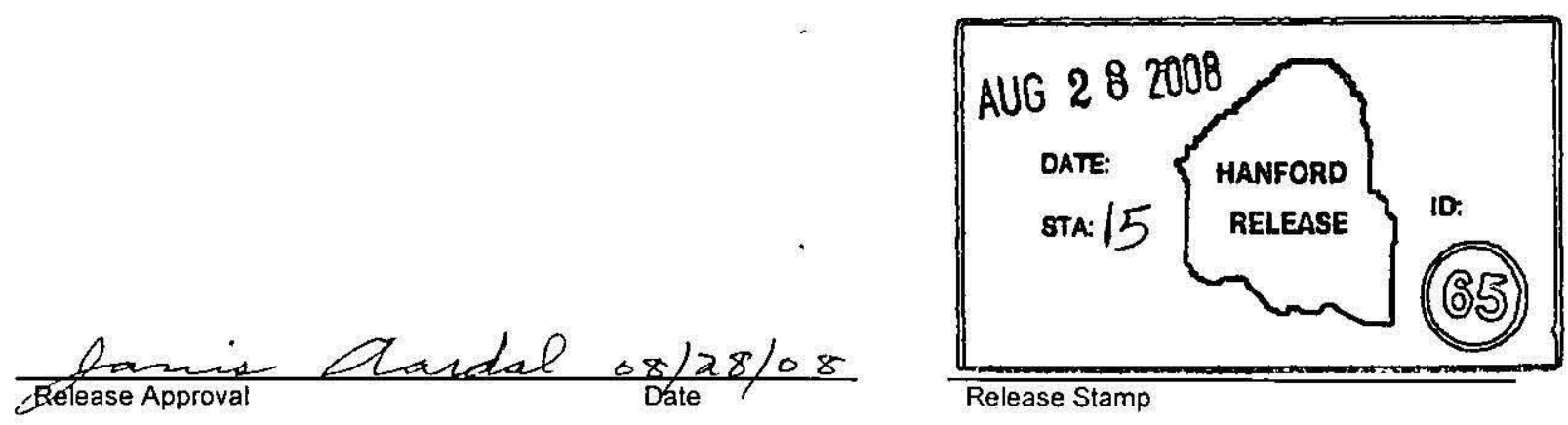

Approved For Public Release 


\title{
Final Report for the Reduction of Chrome (VI) to Chrome (III) in the Secondary Waste Stream of the Effluent Treatment Facility
}

\author{
J. B. Duncan \\ CH2M HILL Hanford Group, Inc.
}

M. D. Guthrie

Fluor Hanford, Inc.

August 2008
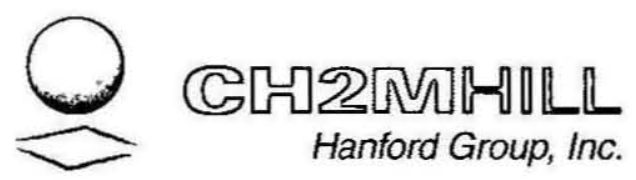

Prepared for the U.S Department of Energy

Office of River Protection

Contract No. DE-AC27-99RL14047

Approved for public release; distribution is unlimited 


\title{
Table of Contents
}

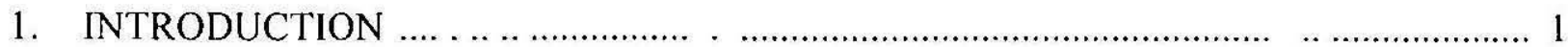

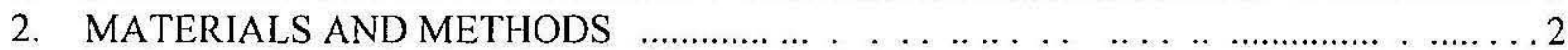

2.1 ELECTROCHEMICAL CORROSION SCANS ............................. . . ............... 2

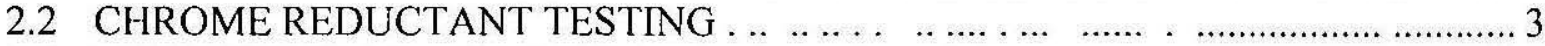

23 TOXICITY CHARACTERISTIC LEACHING PROCEDURE ......... ... ................ 3

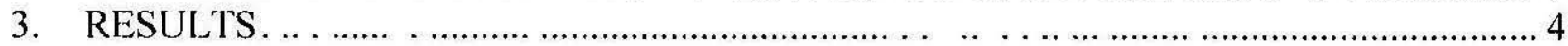

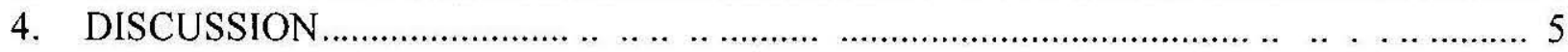

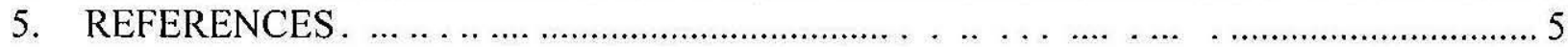

Appendıx A Electrochemical Scans .. . .. . . . . . . .......................... . . . . ... . . A-i

Appendix B Center for Laboratory Sciences Report ......... . . . . . . . . . . . . . ............... B-i

\section{List of Tables}

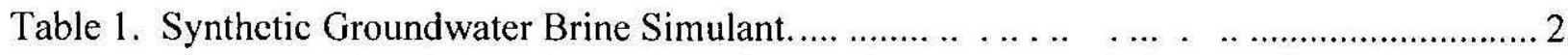

Table 2 Synthetic Groundwater Brinc for Electrochemical Analysis............................. . . . 3

Table 3. Toxicity Characteristic Leaching Procedure Matrix $(+=$ spıke, $-=$ no spıke). ............... 3

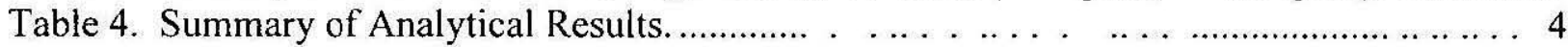

Table 5. Results of Electrochemical Scans ................................................. 5

\section{List of Terms}

\author{
Abbreviations \\ CLS Center for Laboratory Sciences \\ ERDF Environmental Restoration Disposal Facility \\ ETF Effluent Treatment Facility \\ $\mathrm{OCP} \quad$ open circuit potential \\ TCLP Toxicity Characteristic Leaching Procedure
}




\section{INTRODUCTION}

This report documents the laboratory results of RPP-PLAN-35958, Test Plan for the Effluent Treatment Facility to Reduce Chrome (VI) to Chrome (III) in the Secondary Waste Stream.

With the exception of the electrochemical corrosion scans, all work was carried out at the Center for Laboratory Science (CLS) located at the Columbia Basın College. The electrochemical corrosion scans are attached as Appendix A. The full CLS report is attached as Appendix B. This document summarizes the work carried out at CLS and includes the electrochemical scans and associated corrosion rates for 304 and $316 \mathrm{~L}$ stainless steel.

The reduction of $\mathrm{Cr}^{+6}$ to $\mathrm{Cr}^{+3}$ will decrease the mobility of chromium in the environment; allowing the waste stream from the Effluent Treatment Facılity (ETF) thin film dryer to pass the SW-846 Method 1311, "Toxicity Characterıstic Leaching Procedure" (TCLP), for final dısposal in the Environmental Restoratıon Disposal Facility (ERDF) landfill (WHC-191, Environmental Restoration Disposal Facllity Waste Acceptance Criteria). The concentration limits for chromium at the ERDF are established using the chromium limits in Title 40, Code of Federal Regulations, §268.48, "Land Disposal Restrictions - Unıversal treatment standards" (40 CFR 268.48), of $0.6 \mathrm{mg} / \mathrm{L}$ by the TCLP method.

An earlier successful effort used sodium metabisulfite to reduce $\mathrm{Cr}$ (VI) to $\mathrm{Cr}$ (III) under an oxıdation reduction potential of $+280 \mathrm{mV}$ and acidic $(\mathrm{pH} 2)$ conditions (RPP-RPT-34083, Reduction of Chrome(VI) to Chrome(III) using Sodium Metabisulfite under Acidic Condtions).

However, under acidic conditions it was found that the bisulfite attacks the protective chrome coating in 304 and $316 \mathrm{~L}$ and yields the material unsuitable for processing chloride containing water [RPP-RPT-35175, Corrosion Study for the Effluent Treatment Factlity Chrome (VI) Reductant Solution Using 304 and 316 Stainless Steel].

The literature has reported several candidates for the reduction of $\mathrm{Cr}$ (VI) "Alternative Chromium Reduction and Heavy Metal Precipitation Methods for Industrial Wastewater" (Chang 2003) reports on the use of sodium metabisulfite, ferrous sulfate, zero-valent iron, and dimethyl dithiocarbamate From the candidates tested, the sodium metabısulfite and the ferrous sulfate were the most promising (Chang 2003)

"Overview of In Situ Remediation Case Studies," in Chromium (VI) Handbook (Jacobs and Rouse 2005) indicates sodium metabisulfite, hydrogen sulfide, ferrous sulfatc, and calcium polysulfide as suitable reductants.

Since sodium metabisulfite has proven not to be a candidate at the ETF due to corrosion properties, it was therefore elıminated in this study Hydrogen sulfide is considered a dangerous chemical and was not considered in this testing. 
The candidate reductants considered are ferrous sulfate and calcium polysulfide. The respective reactions are the following (Jacobs and Rouse 2005):

Acidic conditions

$$
14 \mathrm{H}^{+}+6 \mathrm{Fe}^{2+}+\mathrm{Cr}_{2} \mathrm{O}_{7}^{2-} \rightarrow 6 \mathrm{Fe}^{3+}+2 \mathrm{Cr}^{3+}+7 \mathrm{H}_{2} \mathrm{O}
$$

Neutral or alkaline .

$$
3 \mathrm{Fe}^{2+}+\mathrm{CrO}_{4}{ }^{2+}+4 \mathrm{H}_{2} \mathrm{O} \rightarrow 3 \mathrm{Fe}^{3+}+\mathrm{Cr}^{3+}+8 \mathrm{OH}
$$

Calcium polysulfide $\left(\mathrm{CaS}_{5}\right)$

$$
10 \mathrm{H}^{+}+2 \mathrm{CrO}_{4}{ }^{2-}+3 \mathrm{CaS}_{5}(\mathrm{~s}) \rightarrow 3 \mathrm{Ca}^{3+}+2 \mathrm{Cr}(\mathrm{OH})_{3}(\mathrm{~s})+15 \mathrm{~S}(\mathrm{~s})+2 \mathrm{H}_{2} \mathrm{O}
$$

Accordıng to "Calcıum polysulfide remediation of hexavalent chromium contamination from chromite ore processing residue" (Graham et al 2002), reaction 3 rapidly reduces $\mathrm{Cr}$ (VI) over a $\mathrm{pH}$ range of 8 to 12 .

\section{MATERIALS AND METHODS}

Synthetic groundwater sımulant brıne was formulated and served as the matrıx for spıkıng

\begin{tabular}{|c|c|}
\hline Compound & Mass (mg) \\
\hline $\mathrm{CaCl}_{2}$ & $13,513.68$ \\
\hline $\mathrm{CaSO}_{4}$ & 65,57951 \\
\hline $\mathrm{K}_{2} \mathrm{SO}_{4}$ & 4,39012 \\
\hline $\mathrm{Mg}\left(\mathrm{NO}_{3}\right)_{2}$ & 46,77369 \\
\hline $\mathrm{NaNO}_{3}$ & 169,9113 \\
\hline $\mathrm{Na}_{2} \mathrm{O} \cdot \mathrm{SiO}_{2}$ & 25,79377 \\
\hline $\mathrm{H}_{2} \mathrm{SO}_{4}{ }^{\mathrm{a}}$ & $67,044.79$ \\
\hline Sum & $393,006.87$ \\
\hline pH range ${ }^{a}$ & 3.5 to 6 \\
\hline
\end{tabular}
chrome (VI) and chrome (III) during the study (Table 1)

Table 1. Synthetic Groundwater Brine Simulant.

${ }^{a}$ If needed, pll will be adjusted with sodium hydroxide or sulfuric acid

\subsection{ELECTROCHEMICAL CORROSION SCANS}

Cyclic potentiodynamic polarızation scans was carried out on the following combinations, using 304 and 316L stainless steel coupons:

a. The groundwater simulant at a $\mathrm{pH}$ of 3.5 to 6 (as formulated).

b. The groundwater simulant with ferrous sulfate at the correct stoichiometry. 
Table 2 is the formulation provided by CLS for electrochemical corrosion testıng.

Table 2. Synthetic Groundwater Brine for Electrochemical Analysis.

\begin{tabular}{|l|c|c|}
\hline \multicolumn{1}{|c|}{ Compound } & Mass (g) & Mass (g) \\
\hline $\mathrm{CaCl}_{2}$ & 13.5136 & 135136 \\
\hline $\mathrm{CaSO}$ & 65.5795 & 655795 \\
\hline $\mathrm{K}_{2} \mathrm{SO}_{4}$ & 4.3901 & 43901 \\
\hline $\mathrm{Mg}\left(\mathrm{NO}_{3}\right)_{2}$ & 467736 & 467736 \\
\hline $\mathrm{NaNO}_{3}$ & 1699113 & 169.9113 \\
\hline $\mathrm{Na}_{2} \mathrm{O}-\mathrm{SlO}_{2}$ & 25.7937 & 257937 \\
\hline $\mathrm{FeSO}_{4}$ & $\mathrm{NA}$ & $139^{\mathrm{a}}$ \\
\hline Deionized water & 6740382 & 6726482 \\
\hline
\end{tabular}

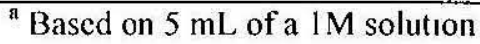

\subsection{CHROME REDUCTANT TESTING}

Based on the anticipated concentration of chrome (VI), synthetic groundwater brine simulant was prepared, chrome (VI) added, and the candidate reductant added in a tımed/volumetric manner.

Final confirmation of the efficacy of the candidate reductant was confirmed by submitting samples to the inductively coupled plasma spectrometry and ion chromatography for total chrome and chrome (VI) concentrations.

\subsection{TOXICITY CHARACTERISTIC LEACHING PROCEDURE}

A TCLP was carried out based on the matrix in Table 3.

Table 3. Toxicity Characteristic Leaching Procedure Matrix (+= spike; - = no spike).

\begin{tabular}{|c|c|c|c|}
\hline $\begin{array}{r}\text { Source } \\
\end{array}$ & pH & Cr (VI) Spike & $\mathrm{Cr}$ (III) Spike \\
\hline \multirow{3}{*}{$\begin{array}{l}\text { Simulated groundwater } \\
(\sim 39 \mathrm{wt} \%)\end{array}$} & 10 & + & + \\
\hline & 11 & + & + \\
\hline & 12 & + & + \\
\hline \multirow{3}{*}{$\begin{array}{l}\text { Sodium sulfate } \\
(\sim 25 w 1 \%)\end{array}$} & 10 & + & + \\
\hline & 11 & + & + \\
\hline & 12 & + & + \\
\hline \multirow{3}{*}{$\begin{array}{l}\text { Ferrous sulfate } \\
\text { [after reaction with } \mathrm{Cr}(\mathrm{VI})]\end{array}$} & 10 & - & - \\
\hline & 11 & - & - \\
\hline & 12 & - & - \\
\hline \multirow{3}{*}{$\begin{array}{l}\text { Calcium polysulfide } \\
\text { [after reaction with } \mathrm{Cr}(\mathrm{VI})]\end{array}$} & 10 & - & - \\
\hline & 11 & - & - \\
\hline & 12 & - & - \\
\hline
\end{tabular}


The solutions indicated in Table 3 were dried at $365^{\circ} \mathrm{F}\left(185^{\circ} \mathrm{C}\right)$ to simulate the ETF drier After drying, a TCLP was carried out to determine what mass of chrome leached.

\section{RESULTS}

Laboratory results from the CLS effort are presented in detail in Appendix B. A discussion of the individual samples for TCLP preparation and the sample specifications are presented in Tables 2 and 3 of Appendıx B. The summary of averaged analytical results are presented in Appendix B and reproduced here in Table 4

Table 4. Summary of Analytical Results.

\begin{tabular}{|c|c|c|c|c|c|}
\hline Leacheate & $\begin{array}{c}\text { Spike } \\
(100 \mathrm{ppm})\end{array}$ & Adjusted $\mathrm{pH}^{\mathrm{a}}$ & $\begin{array}{c}\text { Ferrous } \\
\text { Sulfate } \\
\text { Reduction }\end{array}$ & $\begin{array}{c}\text { Average } \\
\text { Cr(VI) } \\
\text { (ppm) }\end{array}$ & $\begin{array}{c}\text { Average } \\
\text { Total Cr } \\
\text { (ppm) }\end{array}$ \\
\hline $\mathrm{Na}_{2} \mathrm{SO}_{4}$ & $\mathrm{Cr}(\mathrm{III})$ & 10 & NA & 006 & 029 \\
\hline $\mathrm{Na}_{2} \mathrm{SO}_{4}$ & $\mathrm{Cr}(\mathrm{III})$ & 11 & NA & 00032 & 0.057 \\
\hline $\mathrm{Na}_{2} \mathrm{SO}_{4}$ & $\mathrm{Cr}(\mathrm{III})$ & 12 & NA & 0007 & 0.064 \\
\hline $\mathrm{Na}_{2} \mathrm{SO}_{4}$ & $\mathrm{Cr}(\mathrm{VI})$ & 10 & $\mathrm{NA}$ & 18 & 19 \\
\hline $\mathrm{Na}_{2} \mathrm{SO}_{4}$ & $\mathrm{Cr}(\mathrm{VI})$ & 11 & $\mathrm{NA}$ & 15 & 14 \\
\hline $\mathrm{Na}_{2} \mathrm{SO}_{4}$ & $\mathrm{Cr}(\mathrm{VI})$ & 12 & NA & 20 & 20 \\
\hline $\begin{array}{l}\text { Groundwater } \\
\text { simulant }\end{array}$ & $\mathrm{Cr}(\mathrm{III})$ & 10 & NA & 17 & 17 \\
\hline $\begin{array}{l}\text { Groundwater } \\
\text { simulant }\end{array}$ & $\mathrm{Cr}(\mathrm{III})$ & 11 & NA & 3.2 & 16 \\
\hline $\begin{array}{l}\text { Groundwater } \\
\text { simulant }\end{array}$ & $\mathrm{Cr}(\mathrm{III})$ & 12 & NA & 27 & 14 \\
\hline $\begin{array}{l}\text { Groundwater } \\
\text { simulant }\end{array}$ & $\mathrm{Cr}(\mathrm{VI})$ & 10 & Yes & 16 & 19 \\
\hline $\begin{array}{l}\text { Groundwater } \\
\text { simulant }\end{array}$ & $\mathrm{Cr}(\mathrm{VI})$ & 11 & Yes & 16 & 19 \\
\hline $\begin{array}{l}\text { Groundwater } \\
\text { simulant }\end{array}$ & $\mathrm{Cr}(\mathrm{VI})$ & 12 & Yes & 16 & 18 \\
\hline $\begin{array}{l}\text { Groundwater } \\
\text { simulant }\end{array}$ & $\mathrm{Cr}(\mathrm{VI})$ & 10 & NA & 0.18 & 13 \\
\hline $\begin{array}{l}\text { Groundwater } \\
\text { simulant }\end{array}$ & $\mathrm{Cr}(\mathrm{VI})$ & 11 & NA & 0.25 & 12 \\
\hline $\begin{array}{l}\text { Groundwater } \\
\text { simulant }\end{array}$ & $\mathrm{Cr}(\mathrm{VI})$ & 12 & NA & 029 & 71 \\
\hline
\end{tabular}

\footnotetext{
${ }^{\mathrm{a}} \mathrm{The} \mathrm{pH}$ was adjusted prior to evaporation
} 
Table 5 provides the results of the electrochemical scans.

Table 5. Results of Electrochemical Scans.

\begin{tabular}{|c|c|c|c|c|c|c|}
\hline \multirow{3}{*}{ Steel } & \multicolumn{3}{|c|}{$\begin{array}{c}\text { Groundwater Simulant without } \\
\text { Ferrous Sulfate }\end{array}$} & \multicolumn{3}{c|}{$\begin{array}{c}\text { Groundwater Simulant with } \\
\text { Ferrous Sulfate }\end{array}$} \\
\cline { 2 - 7 } & OCP $^{\mathbf{a}}$ & $\begin{array}{c}\text { Corrosion } \\
\text { Rate (mpy) }\end{array}$ & $\boldsymbol{\chi}^{\mathbf{2}}$ & OCP & $\begin{array}{c}\text { Corrosion } \\
\text { Rate (mpy) }\end{array}$ & $\boldsymbol{\chi}^{\mathbf{2}}$ \\
\hline 304 & -161.9 & $1.8 \mathrm{E}-02$ & 862 & -1487 & $2.5 \mathrm{E}-02$ & 2.71 \\
\hline $316 \mathrm{~L}$ & -1689 & $12 \mathrm{E}-02$ & 167 & -164.4 & $138 \mathrm{E}-02$ & 4.29 \\
\hline
\end{tabular}

${ }^{\mathrm{a}} \mathrm{OCP}=$ Open cırcuit potentıal, the rest potentıal of equilibrium potential between the metal and solution

${ }^{\mathrm{b}} \mathrm{mpy}=$ mils per year $(1 \mathrm{mil}=0001 \mathrm{inch})$

${ }^{c} \chi^{2}=$ The goodness-of-fit statıstıc for corrosion rate calculations, a value $<100$ is acceptable

\section{DISCUSSION}

The ferrous sulfate was successful in reducing the $\mathrm{Cr}$ (VI) to $\mathrm{Cr}$ (III) Calcium polysulfide was marginally effective and produced offensive odors durıng the reduction step and therefore was determined to not be a suitable process for the ETF. From the electrochemical scans, general corrosion was approxımately $1 \mathrm{E}-02$ mils per year.

The reduced chrome did exhıbit some partial re-oxidation during the drying process, which yıelded a crystalline form.

The crystalline matrix was subjected to the TCLP. This resulted in complete dissolution of the sample, allowing chrome to no longer be contained in a binding matrix, which allowed it to pass through the filter media during the filtering step. This was due to the elevated solubility of $\mathrm{Cr}(\mathrm{OH})_{3}$ in the slightly acidic conditions for the TCLP leach solution

The process to reduce $\mathrm{Cr}(\mathrm{VI})$ was successful in the groundwater brine To pass TCLP, it is recommended that the reduced brine be grouted in a cementitious matrix.

\section{REFERENCES}

40 CFR 268 48, "Land Disposal Restrictions - Universal treatment standards," Code of Federal Regulations, as amended.

Chang, L., 2003, "Alternative Chromium Reduction and Heavy Metal Precipitation Methods for Industrial Wastewater," Environmental Progress, Vol 22 (3), p 174-182.

Graham, M. C., J. G. Farmer, P. Anderson, E. Paterson, S. Hillier, D. G Lumsdon, and R. J. F. Bewley, 2002, "Calcium polysulfide remediation of hexavalent chromium contamination from chromite ore processing residue," Science of the Total Environment, Vol 364, p 32-44. 
Jacobs, J. A., and J. M. V Rouse, 2005, "Overview of In Situ Remediation Case Studies," in Chromıum (VI) Handbook, J Guertin, J. A. Jacobs, and C. P. Avakian, editors, CRC Press, New York, New York.

RPP-RPT-34083, 2007, Reduction of Chrome(VI) to Chrome(III) using Sodium Metabisulfite under Acidic Conditions, Rev 0, CH2M HILL Hanford Group, Inc., Richland, Washington

RPP-RPT-35175, 2007, Corrosion Study for the Effluent Treatment Facillty Chrome (VI) Reductant Solution Using 304 and 316L Stainless Steel, Rev 0, CH2M HILL Hanford Group, Inc., Richland, Washington

RPP-PLAN-35958, 2008, Test Plan for the Effluent Treatment Facility to Reduce Chrome (VI) to Chrome (III) in the Secondary Waste Stream, Rev. 0, CH2M HILL Hanford Group, Inc., Richland, Washington.

SW-846, Method 1311, 1992, "Toxicity Characterıstıc Leachıng Procedure," Test Methods for Evaluatıng Solid Waste, Physical/Chemical Methods, U.S. Environmental Protection Agency, Washıngton, D.C.

WHC-191, 2008, Environmental Restoratton Disposal Facility Waste Acceptance Criterta, Rev 0, Washıngton Closure Hanford, Richland, Washıngton. 
RPP-RPT-37878, Rev. 0

Appendix A

Electrochemical Scans

A-i 
Figure A-1. 304 Stainless Steel without Ferrous Sulfate, the Reverse Trace is a Negative Hysteresis, Returning to the Left of the Forward Trace.

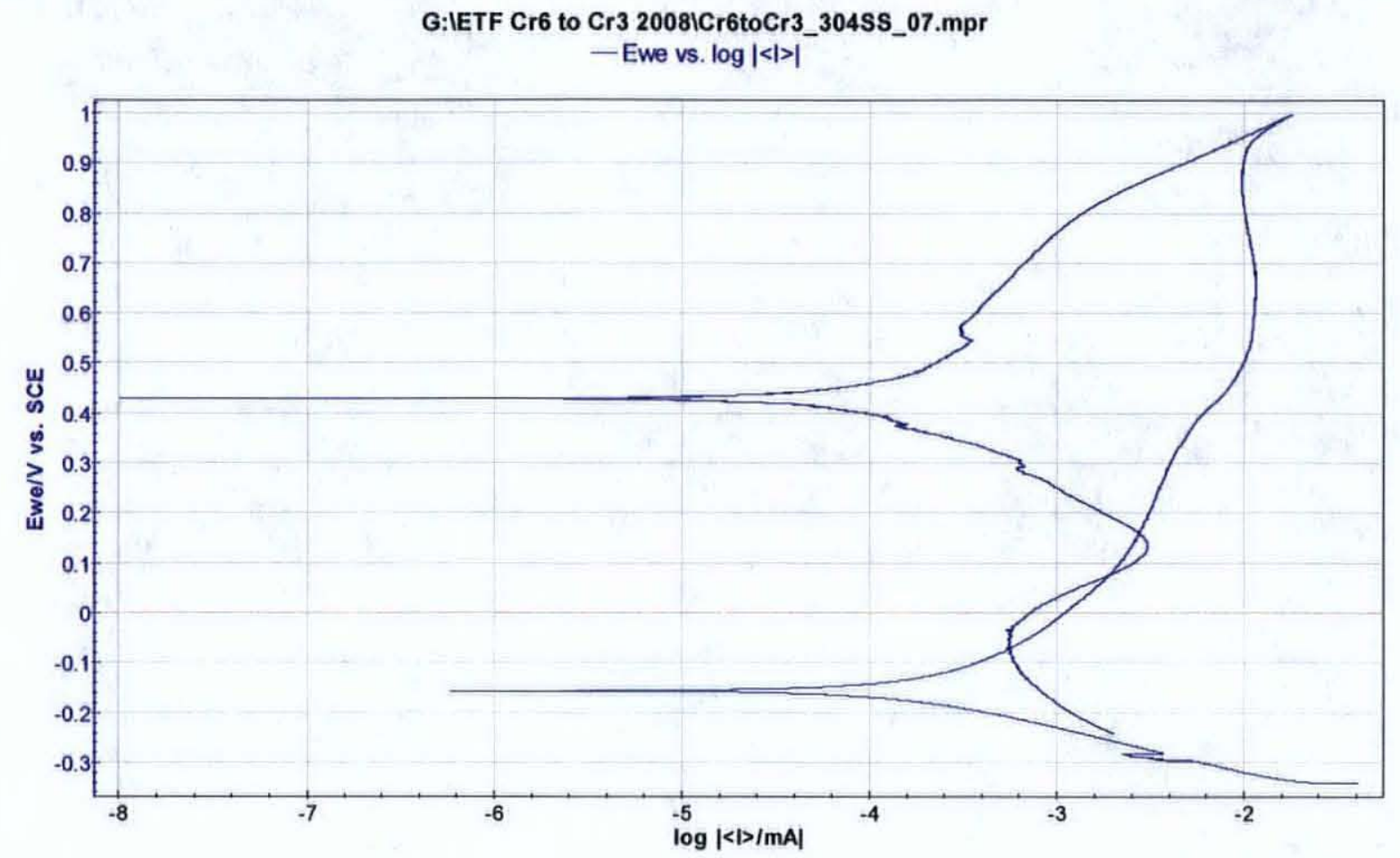




\section{RPP-RPT-37878, Rev. 0}

Figure A-2. 304 Stainless Steel with Ferrous Sulfate, the Reverse Trace is a Negative Hysteresis, Returning to the Left of the Forward Trace.

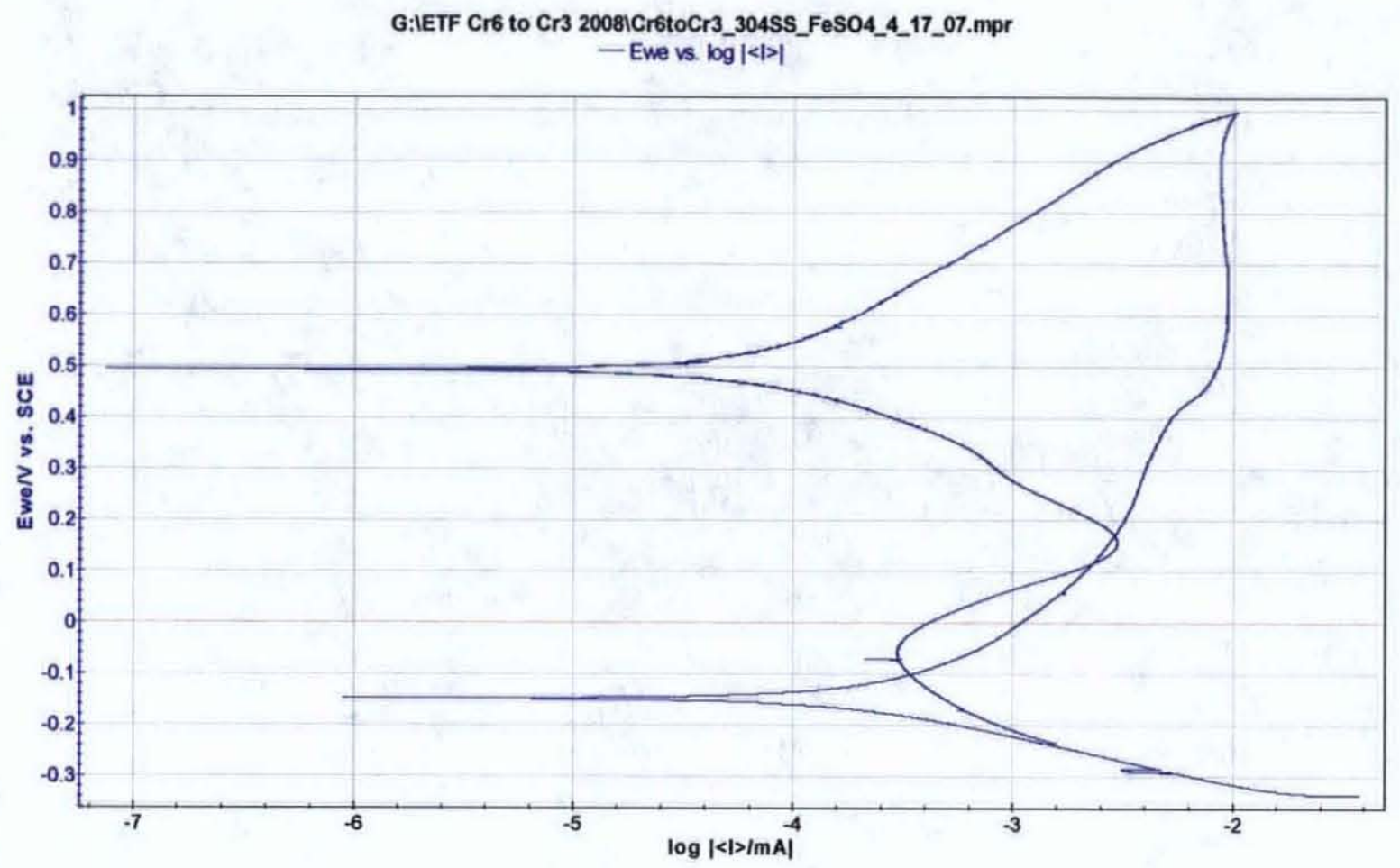


Figure A-3. 316L Stainless Steel without Ferrous Sulfate, the Reverse Trace is a Negative Hysteresis, Returning to the Left of the Forward Trace.

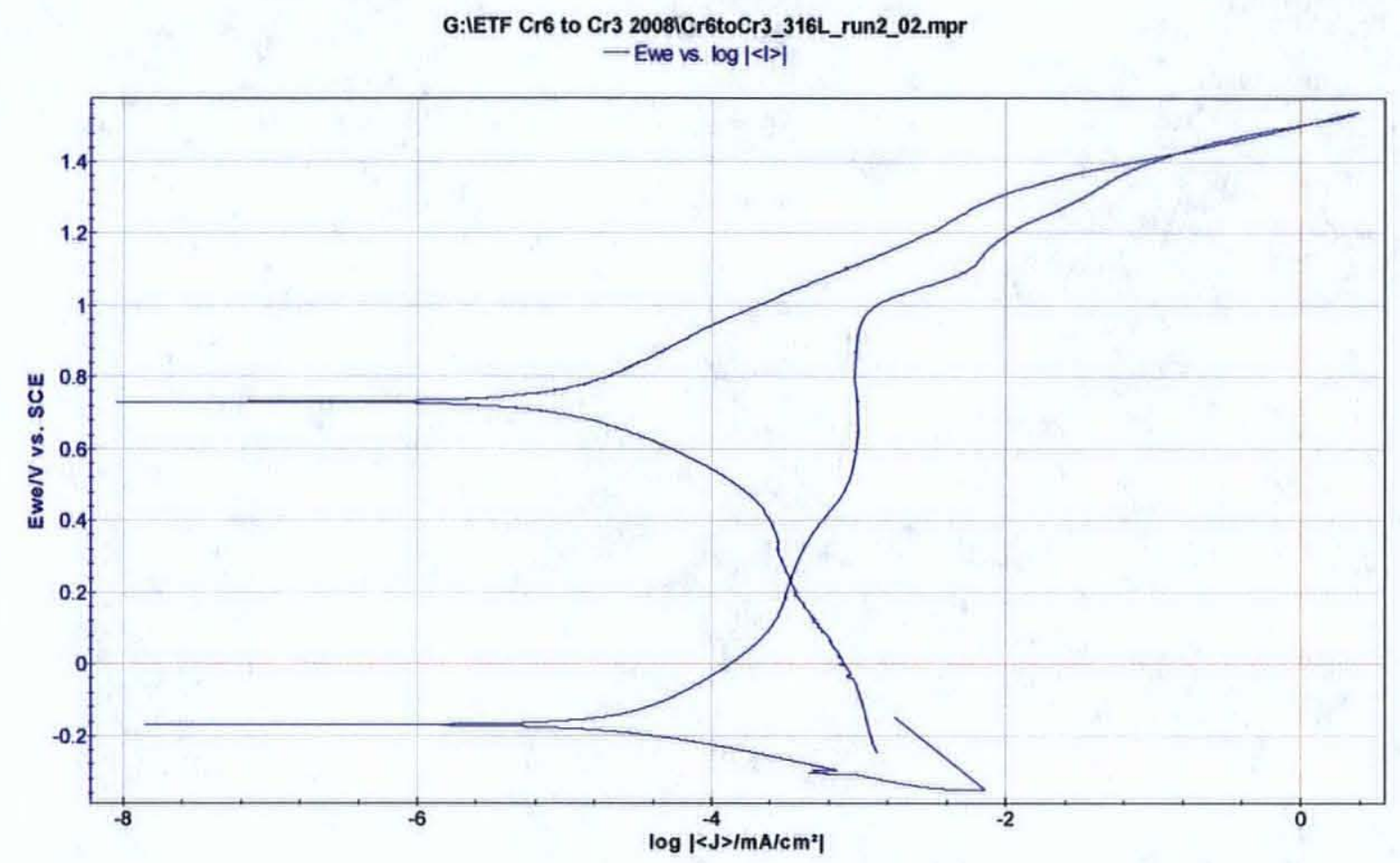


Figure A-4. 316L SS with Ferrous Sulfate, the Reverse Trace is a Negative Hysteresis, Returning to the Left of the Forward Trace.

G:IETF Cr6 to Cr3 2008iCr6toCr3_316L_FeSO4_4_17_02.mpr -Ewe vs. $\log |<|>\mid$

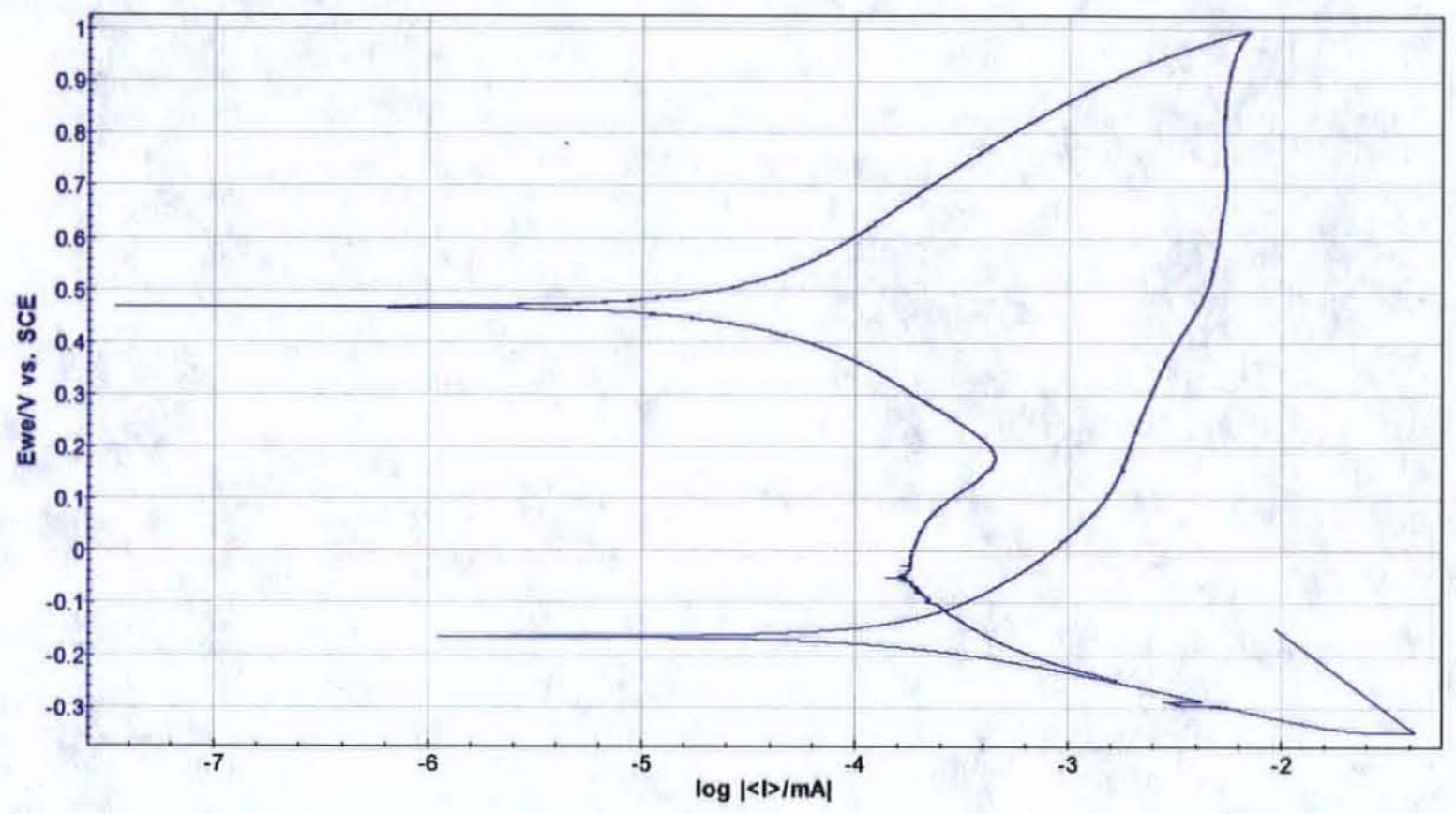


RPP-RPT-37878, Rev. 0

Appendix B

Center for Laboratory Sciences Report 


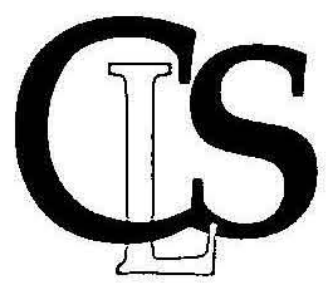

\title{
Effluent Treatment Facility Secondary Waste Stream Chrome Reduction
}

\author{
Laboratory Report
}

Report Date: July 16, 2008

Prepared by:

Glynnis Anne Bowman, CHMM

Operations Manager

RJ LeeGroup, Inc.

Center for Laboratory

Sciences

2710 North $20^{\text {th }}$ Avenuse

Pasco, WA 99301

Prepared for:

CH2M Hill Hanford Group, Inc. RPP PLAN 35958 
RPP-RPT-37878, Rev 0

RJ LeeGroup, Inc Project Number GAL801937

RJ LeeGroup, Inc CLS Document Control Number CLSRPT-0802

RJ LeeGroup, Inc.

Center for Laboratory Sciences

Report for Activities Undertaken at the Center for Laboratory Sciences (CLS) in Support of CH2M Hill Hanford: Report for RPP-PLAN-35958: Test Plan for the Effluent Treatment Facility (ETF) to Reduce Chrome (VI) to Chrome (III) in the Secondary Waste Stream.

Author.

Glynnıs Anne Bowman, CHMM

Operations Manager

RJ LeeGroup, Inc.

Center for Laboratory Sciences 

RPP-RPT-37878, Rev. 0
RJ LeeGroup, Inc Project Number GAL801937
RJ l.eeGroup, Inc CL.S Document Control Number CLSRP [-0802

\section{Table of Contents}

Signatory Page

Page 4

Report

Page 5

Appendix A: Inductively Coupled Plasma-Mass Spectroscopy

Page 17

Analytical Report for Chromium Analysis

Appendix B: Ion Chromatography

Page 21

Analytical Report for Hexavalent Chromium Analysis

Appendix C: Quality Assurance Report

Page 25

Appendix D: Chain of Custody

Page 34

Simulated Groundwater Brine Samples relinquished to 222S. 
Report for Activities Undertaken at the Center for Laboratory Sciences (CLS) in Support of CH2M Hill Hanford: Report for RPP-PLAN-35958: Test Plan for the Effluent Treatment Facility (ETF) to Reduce Chrome (VI) to Chrome (III) in the Secondary Waste Stream

\section{Signatory Page:}

Author:

Glynnis Anne Bowman. CHMM Operations Manager

RJ LeeGroup, Inc.

Center for Laboratory Sciences

Technical Review:

Larry Lockard

Senior Scientist/Engıneer

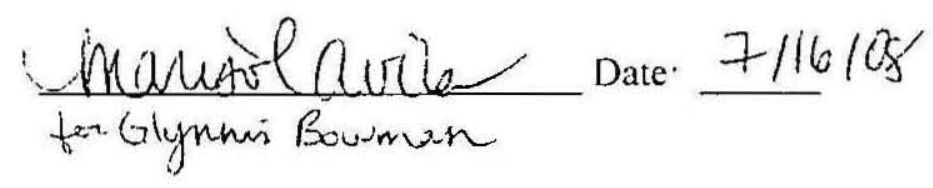

RJ LeeGroup, Inc.

Center for Laboratory Sciences

Technical Review:

Bryanna Mull

Technician

RJ LeeGroup. Inc

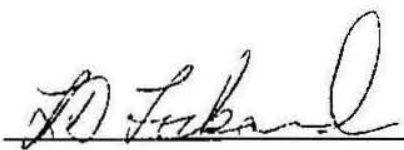

Date: $7 /$ is/or

Center for Laboratory Sciences

Quality Assurance:

Melanie Myers. RSO

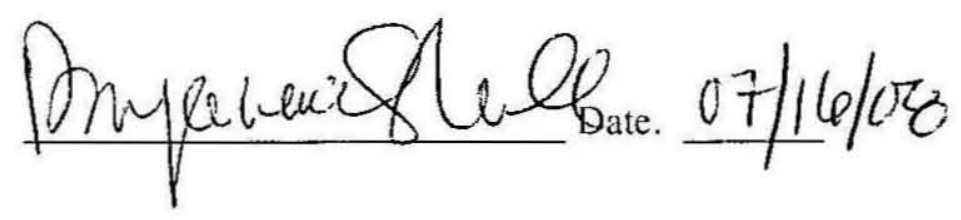

Quality Assurance Manager

RJ LeeGroup. Inc

Center for Laboratory Sciences

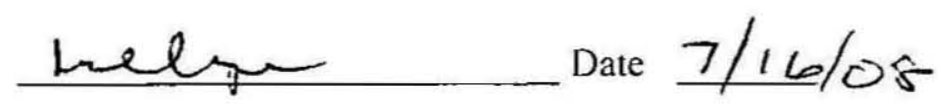


The CLS staff operated under the instructions presented in the $\mathrm{CH} 2 \mathrm{M} \mathrm{H}$ Hll Hanford project Test Plan (RPP-PLAN-35958) and under the guidance of $\mathrm{CH} 2 \mathrm{M}$ Hill and Fluor Hanford technical staff The premise of this test plan is that chromium present in the waste stream in the hexavalent state can be reduced to the less mobile trivalent state and then sequestered so as to be impervious to the acid digestion involved with the EPA Method 1311 Toxıcity Characterıstic Leachıng Procedure (TCLP).

Literature review resulted in several candidate reductants, all of which were excluded within the test plan introduction except for ferrous sulfate and calcium polysulfide Per the test plan, the following chemıcal equilıbria are predıcted to be operatıve during the reductıon actıvitıes:

Neutral or alkaline conditıons

Employıng ferrous sulfate $\left(\mathrm{FeSO}_{4}\right)$ as the reducing agent

$3 \mathrm{Fe}^{2+}{ }_{(\mathrm{aq})}+\mathrm{CrO}_{4}{ }^{2-}{ }_{(\mathrm{aq})}+4 \mathrm{H}_{2} \mathrm{O} \stackrel{\mathrm{NaOHI}}{-}>3 \mathrm{Fe}^{3+}{ }_{(\mathrm{s})}+\mathrm{Cr}^{3+}{ }_{(\mathrm{s})}+8 \mathrm{OH}^{-}$

Acıdic Conditıons.

Employing calcum polysulfide $\left(\mathrm{CaS}_{5}\right)$ as the reducıng agent

$10 \mathrm{H}^{+}+2 \mathrm{CrO}_{4}{ }_{(\mathrm{aq})}^{-}+3 \mathrm{CaS}_{5(\mathrm{~s})} \rightarrow 3 \mathrm{Ca}_{(\mathrm{aq})}^{3+}+2 \mathrm{Cr}(\mathrm{OH})_{3(\mathrm{~s})}+15 \mathrm{~S}_{(\mathrm{s})}+2 \mathrm{H}_{2} \mathrm{O}$

According to both equilibria, the reduction of the hexavalent chromium will result in the precipitation of insoluble chromum (III) hydroxide

Formulation for groundwater brine $(\sim 39 \mathrm{wt} \%)$, sımulated to represent the influent to the Thın Film Dryer at the Effluent Treatment Facility, was provided in the RPP-PLAN-35958 CLS was also instructed to prepare a sodium sulfate solution $(\sim 25 \mathrm{wt} \%)$. The sodium sulfate solution is included in this project to represent a resin regeneration solution employed at ETF.

Evaporatıon of simulated groundwater brine and sodıum sulfate samples spiked with hexavalent chromium and then reduced by the ferrous sulfate or Ca-polysulfide under $185^{\circ} \mathrm{C}$ will simulate the conditıons at the ETF drier. Once desiccated and subjected to Toxicity Leaching Characterıstıc Procedure (TCLP) digestıon, Inductıvely Coupled Plasma-Mass Spectroscopy (ICP-MS) analysıs will address the suitabılity of the waste for disposal 
The actıvities undertaken at CLS fall into six phases'

10 Preparatory Work

1.1 Preparation of the simulated groundwater brine, sodium sulfate and ferrous sulfate solutions

1.2 Fortıfication of the sımulated groundwater brine and sodıum sulfate solution with $\mathrm{Cr}$ (III) and $\mathrm{Cr}$ (VI) standard solutions

2.0 Testing of the reduction of hexavalent chromium to trivalent chromium by ferrous sulfate and calcium polysulfide

30 Preparation of $100 \mathrm{ppm} \mathrm{Cr}$ (III) and $\mathrm{Cr}$ (VI) fortificd sodium sulfate and groundwater simulant samples

40 Preparatıon of the chromıum fortıfied sodium sulfate and groundwater simulant and solutions per EPA method 1311, Toxicity Leachıng Characterıstic Procedure (TCLP)

50 Analysis of TCLP extracts usıng EPA 2008 ICP-MS analysıs for metals and EPA method 218.6 Ion Chromatography (IC) analysis for hexavalent chromıum

6.0 Preparation of sımulated groundwater brine for submıssion to $222 \mathrm{~S}$ for electro-chemıcal analysıs.

\subsection{Preparation of the simulated groundwater brine, sodium sulfate, and ferrous sulfate solutions}

RPP-PLAN-35958 directed a simulated groundwater to be prepared from the reagents and masses as listed in Table 1 The $\mathrm{pH}$ of the solution was to be adjusted with concentrated $\mathrm{H}_{2} \mathrm{SO}_{4}$ to fall in the range of $35-60$.

Table 1: Synthetic Groundwater Brine Simulant Preparation

\begin{tabular}{|c|c|c|c|}
\hline & $\begin{array}{c}\text { RPP-PLAN-35958 } \\
\text { Formulation }\end{array}$ & $\begin{array}{c}\text { RJLG, CLS } \\
\text { Batch 1 }\end{array}$ & $\begin{array}{c}\text { RJLG, CLS } \\
\text { Batch 2 }\end{array}$ \\
\hline Volume Deionized Water & I Liter & 2 Liters & 2 Liters \\
\hline Compound & grams & Actual grams & Actual grams \\
\hline $\mathrm{CaCl}_{2}$ & 13.5136851 & 27.0389 & 270274 \\
\hline $\mathrm{CaSO}_{4}$ & 6557951 & 1311572 & 131159 \\
\hline $\mathrm{K}_{2} \mathrm{SO}_{4}$ & 439012 & 8.7812 & 878024 \\
\hline${\mathrm{Mg}\left(\mathrm{NO}_{3}\right)_{2}}^{\mathrm{NaNO}}$ & 46.77369 & 935602 & 935474 \\
\hline $\mathrm{Na}_{2} \mathrm{O}-\mathrm{StO}_{2}$ & 1699113 & 3398248 & 3398226 \\
\hline
\end{tabular}


The groundwater simulant was prepared in two 2 liter batches as per Table 1 and combined into one 4 liter flask Following thorough mixing, the initial $\mathrm{pH}$ of the sımulated groundwater was 5.92. Titration with concentrated $\mathrm{H}_{2} \mathrm{SO}_{4}$ and monitored with a Thermo-Orion ${ }^{1} 3$-Star $\mathrm{pH}$ meter resulted in the final $\mathrm{pH}$ of 5.43

The groundwater brıne was split into five $400 \mathrm{ml}$ portions and each split was fortıfied to $100 \mathrm{ppm}$ trivalent or hexavalent chromium Section 12 presents the detaıls for the Cr fortifications.

\section{Sodium sulfate solution preparation}

A total of 4 liters of $25 \%$ sodium sulfate solution was prepared in two 2 liter batches as follows

- $500 \mathrm{~g} \mathrm{Na}_{2} \mathrm{SO}_{4}$ (American Chemical Society (ACS) grade 99.0\% minimum) CLSID CI020508QQ was transferred to a clean 2 L class A volumetric flask, certıfication $\# 0007$. Approximately 18 liters of deionized water was added to flask.'

- $\quad 500 \mathrm{~g} \mathrm{Na}_{2} \mathrm{SO}_{4}$ (ACS grade $990 \%$ minimum) CLSID CI020508SS was transferred qualıtatıvely to a clean $2 \mathrm{~L}$ class A volumetrıc Flask, certıfication \#0054 Approximately 18 liters of deıonized water was added to flask

The two volumetric flasks were subjected to agitation on shaker table and heated to induce solution of the $\mathrm{Na}_{2} \mathrm{SO}_{4}$. Once in solution, the flasks were brought to the $2 \mathrm{~L}$ mark with deionized water The sodıum sulfate solution was initıally splıt into three $300 \mathrm{ml}$ and three $660 \mathrm{~mL}$ portions for

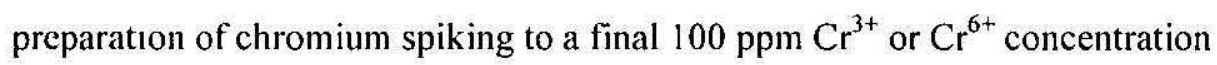

\section{Ferrous sulfate solution preparation:}

A total of $100 \mathrm{ml}$ of ferrous sulfate solution was prepared as follows:

- $\quad 27801 \mathrm{~g} \mathrm{FeSO}_{4}$ (ACS reagent grade) was transferred quantıtatıvely to a $100 \mathrm{ml}$ volumetric flask Deionized water was added to the flask to a final solution volume of $100 \mathrm{ml}$ The ferrous iron concentration was made at 1 molar

\subsection{Fortification of the simulated groundwater brine and sodium sulfate solution with Cr (III) and $\mathrm{Cr}$ (VI) standard solutions}

\footnotetext{
${ }^{1}$ Thermo-Orion is a registered trademark of the Thermo Sc1entufic Corporation. Waltham. Massachusetts.
} 


\section{Trivalent chromium spike solution:}

Single element trivalent chromıum standard at a concentration of 10,000 $\mathrm{g} / \mathrm{mL}$ (Lot \#E00369A, CLS ID \#MR042407G), was employed to generate $100 \mathrm{ppm} \mathrm{Cr}^{3+}$ concentration No preparation of the standard solution was necessary Spıke volume to bring the sodium sulfate and groundwater brıne aliquots to $100 \mathrm{ppm} \mathrm{Cr}^{3+}$ were calculated based on the volume of the alıquot and transferred via pipette.

- Spike volume for $100 \mathrm{ppm} \mathrm{Cr}$ concentration using $\mathrm{Na}_{2} \mathrm{CrO}_{4}$.

$$
\begin{aligned}
V_{\text {intial }}= & \left(\left(V_{\text {final }}\right)\left(C_{\text {firal }}\right)\right) / C_{\text {mintual }} \\
& V_{\text {Intual }} \text { volume of stock reagent required to yicld necessary concentration } \\
& C_{\text {intial }} \text { concentration of stock reagent } \\
& V_{\text {tinal }} \text { linal volume required (sample volume) } \\
& C_{\text {intual }} \text { final concentration required }
\end{aligned}
$$

Example spıke volume to prepare a $100 \mathrm{ppm}$ sodium sulfate solution

$\mathrm{V}_{\text {Intial }}=((0300 \mathrm{~L})(100 \mathrm{mg} / \mathrm{L})) / 10^{4} \mathrm{mg} / \mathrm{L}$

$V_{\text {Int:al }}=3.0 \mathrm{ml} \mathrm{Cr}^{3+}$ standard

\section{Hexavalent Chromium spike material:}

The $\mathrm{Cr}^{6+}$ standard material was composed of a $\mathrm{Na}_{2} \mathrm{CrO}_{4} \cdot 4 \mathrm{H}_{2} \mathrm{O}$ solıd reagent (Lot \#534816, CLS ID \#MR020708A)

- Mass of $\mathrm{Na}_{2} \mathrm{CrO}_{4}$ required for a spike of $100 \mathrm{ppm} \mathrm{Cr}^{6+}$ concentration:

( $\left.\mathrm{FW} \mathrm{Na} 2 \mathrm{CrO}_{4} 4 \mathrm{I}_{2} \mathrm{Og} / \mathrm{mol} / \mathrm{MW} \mathrm{Cr} \mathrm{g/mol}\right)$ * required linal concentration $\mathrm{mg} / \mathrm{L}$ * sample volume $\mathrm{L}$, iters

- $\mathrm{Na}_{2} \mathrm{CrO}_{4} \cdot 4 \mathrm{H}_{2} 0 \mathrm{mg}$ to prepare a $100 \mathrm{ppm} \mathrm{Cr6}{ }^{+}$sample.

$(23404 \mathrm{~g} / \mathrm{mol} / 52 \mathrm{~g} / \mathrm{mol}) * 100 \mathrm{mg} / \mathrm{L} * 0660 \mathrm{~L}=297.05 \mathrm{mg} \mathrm{Na}_{2} \mathrm{CrO}_{4} \cdot 4 \mathrm{H}_{2} \mathrm{O}$

- (for each of three $660 \mathrm{ml} \mathrm{Na} \mathrm{SO}_{4}$ samples)

$(23404 \mathrm{~g} / \mathrm{mol} / 52 \mathrm{~g} / \mathrm{mol}) * 100 \mathrm{mg} / \mathrm{L}, 200 \mathrm{~L},=900.2 \mathrm{mg} \mathrm{Na}_{2} \mathrm{CrO}_{4} \cdot 4 \mathrm{H}_{2} \mathrm{O}$

- (135 $\mathrm{g} \mathrm{Na}_{2} \mathrm{CrO}_{4} 4 \mathrm{H}_{2} \mathrm{O}$ for each of six $300 \mathrm{ml}$ groundwater brınc samples)

\subsection{Testing the reduction of hexavalent chromium to trivalent chromium by ferrous sulfate and calcium polysulfide}

Oxidation/Reduction potential testing of the two hexavalent chromium reductant candidates was conducted by the Fluor Hanford and $\mathrm{CH} 2 \mathrm{M}$ Hıll Hanford technical staff During this testing, calcium 
RJ LeeGroup, Ine Project Number GAL 801937
RJ LeeGroup, Inc CLS Document Control Number CLSRP [-0802

polysulfide was rejected as a potential reducing agent The CLS analytical staff was instructed to continue preparation and analysis with ferrous sulfate as the only reductant. The CLS staff was also instructed to add a $5 \mathrm{ml}$ volume of ferrous sulfate to the fortified simulated groundwater samples decanted for evaporation and TCLP preparation $\left(300 \mathrm{ml}\right.$ total volume at $\left.100 \mathrm{ppm} \mathrm{Cr}^{6+}\right)$. All $\mathrm{HACH}^{2}$ Chromium VI meter testıng was conducted by the Fluor Hanford and $\mathrm{CH} 2 \mathrm{M}$ Hıll Hanford technical personnel

\subsection{Preparation of $100 \mathrm{ppm} \mathrm{Cr}$ (III) and $\mathrm{Cr}$ (VI) sodium and groundwater simulant samples}

Table 2 defines the attributes of fifteen $500 \mathrm{ml}$ beakers prepared for evaporation and eventual TCLP digestıon. Prior to evaporatıon, the solutıons fortıfied with either $\mathrm{Cr}^{3+}$ or $\mathrm{Cr}^{6+}$ were titrated with $\mathrm{NaOH}$ to $\mathrm{pH}$ of 10,11 and 12 .

The beakers were then subjected to evaporation in a two step process. The initial evaporation occurred in a $95^{\circ} \mathrm{C}$ oven for approxımately 110 hours The temperature was then elevated to $185^{\circ} \mathrm{C}$ for an additional 24 hours.

During evaporatıon, the sodium sulfate solutions formed large well defined crystals. The evaporated groundwater samples dried to solıd dense materıal.

Table 2 presents the aliquots of the sodıum sulfate and groundwater samples that were established for evaporation for final TCLP digestion and analysıs The table also illustrates the trivalent and hexavalent chromium spiking and reduction by ferrous sulfate where appropriate. 
RPP-RPT-37878, Rev. 0

RJ LeeGroup, Inc Project Number GAL801937

RJ l.ceGroup, Inc CLS Document Control Number CLSRPT-0802

Table 2: Sample Specifics for TCLP Preparation

\begin{tabular}{|c|c|c|c|c|c|c|c|}
\hline Source & $\begin{array}{c}\mathrm{NaOH} \\
\text { adjusted } \\
\text { pH }\end{array}$ & $\begin{array}{c}\mathrm{Cr} \\
\text { Fortification }\end{array}$ & $\begin{array}{c}\text { Total } \\
\text { Alıquot } \\
\text { Volume } \\
(\mathrm{mL}) \\
\end{array}$ & $\begin{array}{c}\text { Spike } \\
\text { Volume or } \\
\text { mg for } 100 \\
\text { ppm }\end{array}$ & $\begin{array}{l}\text { Ferrous } \\
\text { Sulfate } \\
\text { Reduction }\end{array}$ & \multicolumn{2}{|c|}{ ICP/MS and IC Sample IDs } \\
\hline \multirow{6}{*}{$\begin{array}{l}\text { Sodium Sulfate } \\
\qquad(25 w t \%)\end{array}$} & 10 & $\mathrm{Cr}^{3+}$ & 300 & $3.0 \mathrm{ml}$ & No & WA030120080048 & $001-003$ \\
\hline & 11 & $\mathrm{Cr}^{3+}$ & 300 & $30 \mathrm{ml}$ & No & WA030120080048 & $004-006$ \\
\hline & 12 & $\mathrm{Cr}^{3+}$ & 300 & $30 \mathrm{ml}$ & No & WA030120080048 & 007-009 \\
\hline & 10 & $\mathrm{Cr}^{6+}$ & 660 & $29705 \mathrm{mg}$ & No & WA030120080048 & 010-012 \\
\hline & 11 & $\mathrm{Cr}^{6+}$ & 660 & $29705 \mathrm{mg}$ & No & WA030120080048 & 013-015 \\
\hline & 12 & $\mathrm{Cr}^{6+}$ & 660 & $29705 \mathrm{mg}$ & No & WA030120080048 & 016-018 \\
\hline \multirow{9}{*}{$\begin{array}{c}\text { Sımulated } \\
\text { Groundwater } \\
\text { Brıne }\end{array}$} & 10 & $\mathrm{Cr}^{3+}$ & 300 & $30 \mathrm{ml}$ & No & WA030120080048 & 019-021 \\
\hline & 11 & $\mathrm{Cr}^{3+}$ & 300 & $30 \mathrm{ml}$ & No & WA030120080048 & 022-024 \\
\hline & 12 & $\mathrm{Cr}^{3+}$ & 300 & $30 \mathrm{ml}$ & No & WA030120080048 & 025-027 \\
\hline & 10 & $\mathrm{Cr}^{6+}$ & 300 & $135 \mathrm{mg}$ & No & WA0301 20080048 & $028-030$ \\
\hline & 11 & $\mathrm{Cr}^{6+}$ & 300 & $135 \mathrm{mg}$ & No & WA030120080048 & 031-033 \\
\hline & 12 & $\mathrm{Cr}^{6+}$ & 300 & $135 \mathrm{mg}$ & No & WA030120080048 & $034-036$ \\
\hline & 10 & $\mathrm{Cr}^{6+}$ & 300 & $135 \mathrm{mg}$ & $6 \mathrm{ml}$ & WA030120080048 & 037-039 \\
\hline & 11 & $\mathrm{Cr}^{6+}$ & 300 & $135 \mathrm{mg}$ & $6 \mathrm{mI}$ & WA030120080048 & $040-042$ \\
\hline & 12 & $\mathrm{Cr}^{6+}$ & 300 & $135 \mathrm{mg}$ & $6 \mathrm{ml}$ & WA030120080048 & 043-045 \\
\hline
\end{tabular}

4.0 Preparation of the evaporated groundwater simulants and Sodium Sulfate solutions using EPA method 1311 (RJLG, CLS LAP-032) Toxicity Leaching Characteristic Procedure (TCLP)

Once evaporated, the remaining solids were pulverized in their containers $(500 \mathrm{~mL}$ beakers) Approximately $5 \mathrm{~g}$ from each of the pulverized solids were tested for determmation of extraction fluid per EPA1311

EPA Method 1311 specifies leaching material in one of two extraction flusds based on the $\mathrm{pH}$ of a $5 \mathrm{~g}$ sample in deıonized water If the $\mathrm{pH}$ is $<5$ then extraction fluid \#1 is used Extraction fluid \#2 is 
used for a $\mathrm{pH}$ of $>5$ which requires the use of $3.5 \mathrm{~mL}$ of $1 \mathrm{~N} \mathrm{HCL}$ and heating to 50 degrees $\mathrm{C}$. The test sample is maintained at 50 degrees $\mathrm{C}$ and then allowed to come to room temperature. The method further requires a leachant to leachate ratio of 1: 20 .

The evaporated sodium sulfate solutions required the use of extraction fluid \#2, while the evaporated groundwater simulants required extraction fluid \#1. Approximately $100 \mathrm{~g}$ of solids were used for leaching all TCLP preparations. Table 3 provides the TCLP sample specifics.

The extraction fluid and $100 \mathrm{~g}$ portions were rotated at $30 \mathrm{RPM}$ for a period of 18 hours at room temperature (23 degrees $\mathrm{C}$ plus or minus 2 degrees) room temp, in accordance with EPA 1311. During the rotation process sample WA100320080048 (007-009) leaked approximately $40 \%$ of its solution. Rotation continued to completion once the spill was contained and cleaned.

As Figure 1 illustrates, the CrVI fortified samples exhibited strong color providing visual indication of the dominate chromium oxidation state.

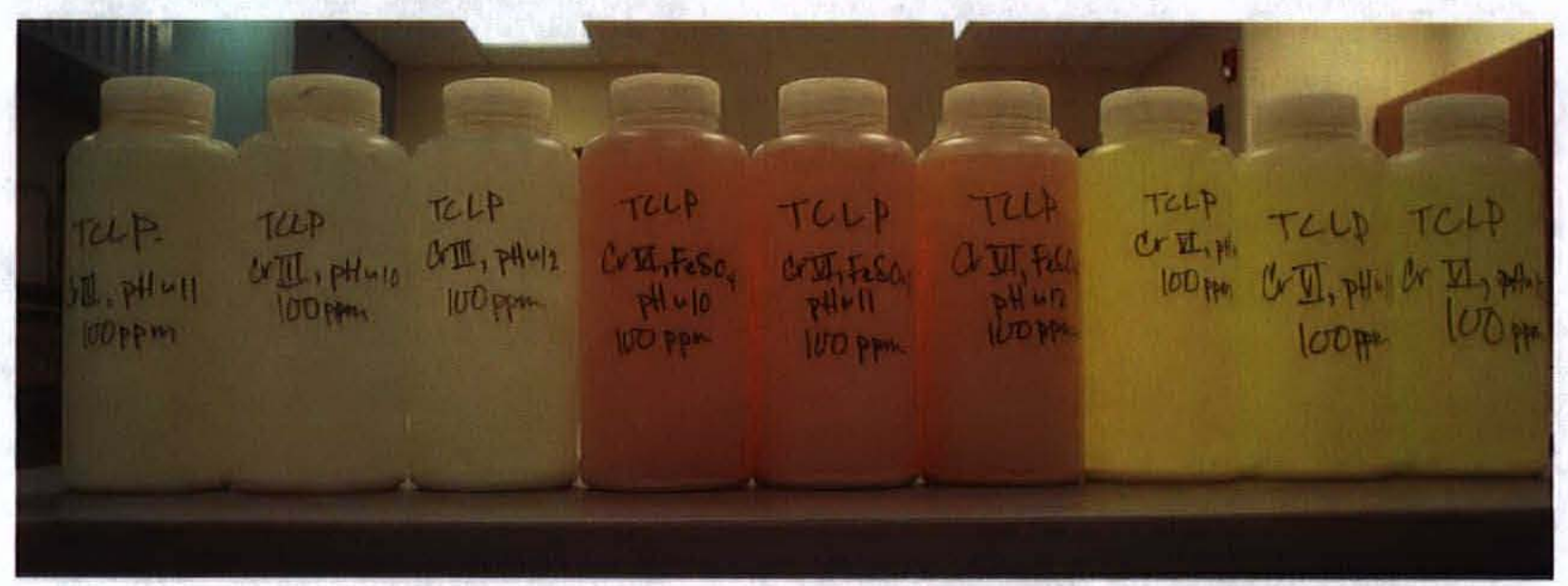

Figure 1 Post TCLP Leached Groundwater Samples

At the conclusion of the rotation process it was evident that the greater portion of the 100 grams of solids exposed to the TCLP extraction solution in each TCLP extract dissolved. The undissolved solids from the simulated groundwater simulant formed a heavy white particulate. When agitated, this particulate settled rapidly to the bottom of the container. Therefore, the groundwater simulants were not filtered prior to further digestion. 
RPP-RPT-37878, Rev. 0

RJ LeeGroup, Inc CLS Document Control Number CLSRPT-0802

Table 3: TCLP Sample Specifications

\begin{tabular}{|c|c|c|c|c|c|c|c|}
\hline Source & $\mathrm{ICP} / \mathrm{MS}$ and IC S & mple IDs & $\begin{array}{c}\mathrm{Cr} \\
\text { Fortification }\end{array}$ & $\begin{array}{l}\text { grams of } \\
\text { Sample for } \\
\text { Extraction } \\
\text { Fluid }\end{array}$ & $\begin{array}{l}\text { grams of } \\
\text { Sample for } \\
\text { Digestion }\end{array}$ & $\begin{array}{l}\text { Extraction } \\
\text { Fluid }\end{array}$ & $\begin{array}{l}\text { gram of } \\
\text { Extraction } \\
\text { Fluid }\end{array}$ \\
\hline \multirow{6}{*}{$\begin{array}{l}\text { Sodium Sulfate } \\
\text { (25 wt \%) }\end{array}$} & WA030120080048 & $001-003$ & $\mathrm{Cr}^{3+}$ & 50463 & 712 & 2 & 14275 \\
\hline & WA030120080048 & 004-006 & $\mathrm{Cr}^{3+}$ & 49891 & 688 & 2 & 13772 \\
\hline & WA030120080048 & $007-009$ & $\mathrm{Cr}^{3+}$ & 5038 & 687 & 2 & 13945 \\
\hline & WA030120080048 & 010-012 & $\mathrm{Cr}^{6+}$ & 50009 & 1003 & 2 & 2005.8 \\
\hline & WA030120080048 & 013-015 & $\mathrm{Cr}^{6+}$ & 50497 & 1003 & 2 & 20064 \\
\hline & WA030120080048 & 016-018 & $\mathrm{Cr}^{6+}$ & 51486 & 100 & 2 & 20017 \\
\hline \multirow{9}{*}{$\begin{array}{l}\text { Simulated } \\
\text { Groundwater } \\
\text { Brıne }\end{array}$} & WA030120080048 & 019-021 & $\mathrm{Cr}^{3+}$ & 51949 & 48.7023 & 1 & 974046 \\
\hline & WA030120080048 & $022-024$ & $\mathrm{Cr}^{3+}$ & 50762 & 489396 & 1 & 978792 \\
\hline & WA030120080048 & 025-027 & $\mathrm{Cr}^{3+}$ & 50022 & 505696 & 1 & 1011392 \\
\hline & WA030120080048 & $028-030$ & $\mathrm{Cr}^{6+}$ & 5.0585 & 502193 & 1 & 1004386 \\
\hline & WA030120080048 & $031-033$ & $\mathrm{Cr}^{6+}$ & 50606 & 473263 & 1 & 946.526 \\
\hline & WA030120080048 & $034-036$ & $\mathrm{Cr}^{6+}$ & 5107 & 463983 & 1 & 927966 \\
\hline & WA030120080048 & 037-039 & $\mathrm{Cr}^{6+}(\mathrm{R})$ & 50703 & 50.416 & 1 & 100832 \\
\hline & WA030120080048 & 040-042 & $\mathrm{Cr}^{6+}(\mathrm{R})$ & 50745 & 492752 & 1 & 985704 \\
\hline & WA030120080048 & 043-045 & $\mathrm{Cr}^{6+}(\mathrm{R})$ & 50841 & 48.8004 & 1 & 976008 \\
\hline
\end{tabular}

(R) Indicates reduction with $\mathrm{FeSO}_{4}$

\subsection{Analysis of TCLP extracts using EPA 200.8 ICP/MS analysis for metals and EPA method 300.0 IC analysis for hexavalent chromium}

The TCLP extracts produced from section III were prepared for analysis of total Cr by ICP-MS To ensure data validations, three samples of each TCLP leachate were drawn from the parent solution for 
total chromium analysis The TCLP extracts were digested and prepared according to EPA method 3005A, "Acid Digestion of Waters for Total Recoverable or Dissolved Metals for analysis by FLAA or ICP Spectroscopy" Following preparation, all samples were analyzed using EPA method 2008 (RJLG, CLS LAP-030), "Determınation of Trace Elements in Waters and Wastes by ICP-MS"

An additional 3 samples were drawn from each leachate for hexavalent chromium analysis The samples were prepared and analyzed by EPA method 218.6 (RJLG, CLS LAP-007) "Determination of Hexavalent Chromium in Drınkıng Water, Groundwater and Industrial Wastewater Effluents and in PVC Filters by Ion Chromatography using EPA Method 218.6"

\section{Discussion of Analytical Results}

The complete total chromium (ICP-MS analysis) and hexavalent chromium (IC analysis) analytical reports are presented in attachments A and B respectively Table 4 presents a summary of the averaged values for each TCLP leachate.

The $\mathrm{pH}$ of the post rotation TCLP extracts was approxımately 4-6 for all samples. According to the redox equilibria for iron sulfate and sodium chromate in the presence of sodium hydroxide, the ferrous Iron reduces chromium in the hexavalent oxidation state to the trivalent oxidation state

$$
3 \mathrm{Fe}^{2+}{ }_{(\mathrm{aq})}+\mathrm{CrO}_{4}{ }^{2-}{ }_{(\mathrm{aq})}+4 \mathrm{H}_{2} \mathrm{O} \stackrel{\mathrm{NaOH}}{-}_{-} 3 \mathrm{Fe}^{3+}{ }_{(\mathrm{s})}+\mathrm{Cr}^{3+}{ }_{(\mathrm{s})}+9 \mathrm{OH}^{-}
$$

Based on the above equation, the resulting chromium product should then be insoluble $\mathrm{Cr}(\mathrm{OH})_{3}$ $\mathrm{Cr}(\mathrm{OH})_{3}$ is relatively insoluble in a pH range of 7.0 to 85 . Based on the total chromium ICP-MS results ( $>5 \mathrm{ppm}$ chrome for all groundwater samples) the $\mathrm{pH}$ adjustment to 10,11 and 12 did not maintain chromıum in an insoluble state throughout the preparation and analytıcal processes

Following the TCLP extraction the $\mathrm{pH}$ of the solutions was in the range of 4-6. The TCLP leaching process in the acidic environment of extraction fluids resulted in the dissolution of the $\operatorname{Cr}(\mathrm{OH})_{3}$ Visual inspection of the extracts supports this conclusion as does the ICP-MS data. The average total chromium results from the ICP-MS data are relatively simılar throughout the experıment regardless of the addition of the ferrous sulfate. The ICP-MS results demonstrate the inability of the $\mathrm{pH}$ adjustment 
and $\mathrm{FeSO}_{4}$ reduction to sequester the chromium such that the TCLP extraction according to EPA Method 1311 will not mobilize the chrome

However, the IC results for the $\mathrm{FeSO}_{4}$ reduced samples indicates that the reduction of the hexavalent chromium is stable following the TCLP extraction The IC preparation and analysis of the 3 TCLP solutions fortified to $100 \mathrm{ppm} \mathrm{Cr}{ }^{6+}$ and the 3 TCLP solutions fortified to $\mathrm{Cr}^{6+}$ and reduced with $\mathrm{FeSO}_{4}$ was performed twice to verify the resultıng hexavalent chromium concentrations. In both analytical runs, the hexavalent chromium concentrations were less than $1 \mathrm{ppm}$ The preparation for IC analysis requires adjustment of the $\mathrm{pH}$ to 9 The solutions were visually inspected following this adjustment, and no color change was evident. From a qualitatıve perspectıve, this supports the actual ion chromatography results

The ICP-MS and IC analysis of the sodium sulfate fortified to $100 \mathrm{ppm}$ trivalent chromım has been rejected for reporting purposes The reaction of a sodium sulfate solution fortıfied with $100 \mathrm{ppm} \mathrm{Cr}^{3+}$ and subjected to $\mathrm{pH}$ adjustment with $\mathrm{NaOH}$ does not support the sequestering of chromium. 
RJ LeeGroup, Inc Project Number GAL801937

RJ LeeGroup, Inc CI.S Document Control Number CLSRP 1.0802

Table 4: Summary of Analytical Results

\begin{tabular}{|l|l|l|c|c|c|c|}
\hline $\begin{array}{c}\text { Sample } \\
\text { IDs }\end{array}$ & \multicolumn{1}{|c|}{ Leachate Description } & Fortification & $\begin{array}{c}\text { Adjusted } \\
\mathrm{pH}\end{array}$ & $\begin{array}{c}\mathrm{FeSO}_{4} \\
\text { Reduction }\end{array}$ & $\begin{array}{c}\text { Average } \\
\mathrm{Cr} 6^{+} \\
\mathrm{ppm}\end{array}$ & $\begin{array}{c}\text { Average } \\
\text { Total Cr } \\
\mathrm{ppm}\end{array}$ \\
\hline $001-003$ & Sodium Sulfate & $100 \mathrm{ppm} \mathrm{Cr}^{3+}$ & 10 & & 0060 & 029 \\
\hline $004-006$ & Sodium Sulfate & $100 \mathrm{ppm} \mathrm{Cr}^{3+}$ & 11 & & 00032 & 0057 \\
\hline $007-009$ & Sodium Sulfate & $100 \mathrm{ppm} \mathrm{Cr}^{3+}$ & 12 & & 00070 & 0.064 \\
\hline $010-012$ & Sodium Sulfate & $100 \mathrm{ppm} \mathrm{Cr}^{6+}$ & 10 & & 18 & 19 \\
\hline $013-015$ & Sodium Sulfate & $100 \mathrm{ppm} \mathrm{Cr}^{6+}$ & 11 & & 15 & 14 \\
\hline $016-018$ & Sodium Sulfate & $100 \mathrm{ppm} \mathrm{Cr}^{6+}$ & 12 & & 20 & 20 \\
\hline $019-021$ & Groundwater Simulant & $100 \mathrm{ppm} \mathrm{Cr}^{3+}$ & 10 & & 17 & 17 \\
\hline $022-024$ & Groundwater Simulant & $100 \mathrm{ppm} \mathrm{Cr}^{3+}$ & 11 & & 3.2 & 16 \\
\hline $025-027$ & Groundwater Simulant & $100 \mathrm{ppm} \mathrm{Cr}^{3+}$ & 12 & & 2.7 & 14 \\
\hline $028-030$ & Groundwater Simulant & $100 \mathrm{ppm} \mathrm{Cr}^{6+}$ & 10 & & 16 & 19 \\
\hline $031-033$ & Groundwater Simulant & $100 \mathrm{ppm} \mathrm{Cr}^{6+}$ & 11 & & 16 & 19 \\
\hline $034-036$ & Groundwater Simulant & $100 \mathrm{ppm} \mathrm{Cr}^{6+}$ & 12 & & 16 & 18 \\
\hline $037-039$ & Groundwater Simulant & $100 \mathrm{ppm} \mathrm{Cr}^{6+}$ & 10 & Yes & 0.18 & 13 \\
\hline $040-042$ & Groundwater Simulant & $100 \mathrm{ppm} \mathrm{Cr}^{6+}$ & 11 & Yes & 0.25 & 12 \\
\hline $043-046$ & Groundwater Simulant & $100 \mathrm{ppm} \mathrm{Cr}^{6+}$ & 12 & Yes & 0.29 & 7.1 \\
\hline
\end{tabular}




\author{
RJ LeeGroup, Inc Project Number GAL801937 \\ RJ LeeGroup, Inc CLS Document Control Number CI.SRPT-0802
}

\title{
6.0 Preparation of simulated groundwater brine for submission to $222 \mathrm{~S}$ for electro-chemical analysis
}

Table 5: Synthetic Groundwater Brine Simulant Preparation for ElectroChemical Analysis at 2225

\begin{tabular}{|c|c|c|c|}
\hline Volume Detonized Water & $\begin{array}{c}\text { RPP-PLAN-35958 } \\
\text { Formulation }\end{array}$ & $\begin{array}{c}\text { RJLG, CLS } \\
\text { Batch 3 }\end{array}$ & $\begin{array}{c}\text { RJLG, CLS } \\
\text { Batch 4 }\end{array}$ \\
\cline { 2 - 4 } & 1 Liter & 1 Liter & 1 Liter \\
\hline $\mathrm{CaCl}_{2}$ & grams & $\begin{array}{c}\text { Actual } \\
\text { grams }\end{array}$ & $\begin{array}{c}\text { Actual } \\
\text { grams }\end{array}$ \\
\hline $\mathrm{CaSO}_{4}$ & 135136851 & 135167 & 13.5130 \\
\hline $\mathrm{K}_{2} \mathrm{SO}_{4}$ & 65.57951 & 655801 & 656084 \\
\hline $\mathrm{Mg}_{2}\left(\mathrm{NO}_{3}\right)_{2}$ & 439012 & 43897 & 44046 \\
\hline $\mathrm{NaNO}_{3}$ & 4677369 & 467715 & 467690 \\
\hline $\mathrm{Na}_{2} \mathrm{O}_{-} \mathrm{SlO}_{2}$ & 1699113 & 1699092 & 169.9201 \\
\hline
\end{tabular}

Two additional batches of the groundwater brine simulant were prepared per the above table for electrochemical analysis The $\mathrm{pH}$ of both batches was approximately 5 A $5 \mathrm{ml}$ volume of $1 \mathrm{M} \mathrm{FeSO}_{4}$ was added to batch 4 The two 1 liter sımulated groundwater brıne sımulants were manıfested to $\mathrm{CH} 2 \mathrm{M}$ Hill Hanford on April 4, 2008 (the chain of custody is attached as appendix D)

All work on this project was performed in conjunction with all hygiene and safety precautions as prescribed in the CLS Chemical Hygiene/Safety Plan, CLS Quality Assurance Manual and the Hanford Analytıcal Services Quality Assurance Requirements Document.

All samples created during this project will be archıved at the RJ Lee Group CLS facility for 90 days or relınquished to $\mathrm{CH} 2 \mathrm{M}$ Hill. Actıve chain of custody will be maintained untıl final disposal or transfer of custody 'All waste including samples at the end of the archival period unless manifested to $\mathrm{CH} 2 \mathrm{M}$ Hill Hanford will be disposed of per applicable federal and state regulations Quality assurance operatıons were documented throughout the project as prescribed in the CLS Quality Assurance Plan 
RPP-RPT-37878, Rev. 0

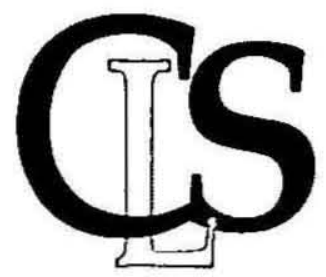

\section{APPENDIX A}

\section{Inductively Coupled Plasma-MS Analytical Reports}

Prepared by:

Glynnis Anne Bowman, CHMM Operations Manager

RJ LeeGroup, Inc. Center for Laboratory Sciences

2710 North $20^{\text {th }}$ Avenue

Pasco. WA 99301 


\section{CH2M Hill}

P O Box 1500

Richland, WA 99352

Atth Larry Lockrem

Phone (509)373-4711

Fax

RJLG Job No WA100320080048 Total Chromium

Analysis Method EPA 200 8, Non-Potable Wate
Tel (509) 545-4989 I Fax (509) 54-6010

RJ Lee Group Job No WA100320080048

Sample Collection 2/8/2008

Samples Received $3 / 10 / 2008$

Report Date $7 / 15 / 2008$

Analysis/Prep Date 3/14/2008

Preparation Method EPA 1311

Chent Project Chrome VI -

GAL 801937

\section{RJ Lee Croup ID}

\section{Sample ID}

Sodıum Sulfate adjusted to $\mathrm{pH} 10 \mathrm{Cr} 3+$ Spıke SS pH $10-1$ TCLP Cr $3+(\mathrm{NR})$ SS pl 1 10-2 TCLP Cr $3+(\mathrm{NR})$ SS pH 10-3 TCLP Cr3+ (NR)

Sodıum Sulfate adjusted to $\mathrm{pH} 11 \mathrm{Cr} 3+$ Spike SS $\mathrm{pH}$ 11-1 TCLP Cr3+ (NR)

SS $\mathrm{pH} 11-2$ TCLP Cr $3+(\mathrm{NR})$

SS PH 11.3 TCLP Cr3+ (NR)

Sodium Sulfate adjusted to $\mathrm{pH} 12 . \mathrm{Cr} 3+$ Spike SS $\mathrm{pH} 12-1$ TCLP Cr $3+(\mathrm{NR})$

SS PH 12-2 TCLP Cr3+ (NR)

SS $\mathrm{pH} 12-3$ TCLP Cr3+ (NR)

Sodium Sulfate adjusted to $\mathrm{pH} 10 . \mathrm{Cr} 6+$ Spike. $\mathrm{SS} \mathrm{pH} \mathrm{10-1} \mathrm{TCLP} \mathrm{Cr6+} \mathrm{(NR)}$ SS pH 10-2 TCLP Cr6+ (NR) SS pH 10-3 TCLP Cr6+ (NR)

Sodıum Sulfate adjusted to $\mathrm{pH} 11 . \mathrm{Cr} 6+$ Spıke SS pH 11-1 TCLP Cr6+ (NR) SS pH 11-2 TCLP Cr6+ (NR) SS pH11-3 TCLP Cr6+(NR)

Sodium Sulfate adjusted to $\mathrm{pH} 12 . \mathrm{Cr} 6+$ Spike SS pH 12-1 TCLP Cr6+ (NR) SS $\mathrm{pH} 12-2 \mathrm{TCLP} \mathrm{Cr} 6+(\mathrm{NR})$ SS pH 12-3 ICLP Cr6+ (NR)

WA100320080048-001

WA100320080048-002

WA100320080048-003

AVERAGE

WA100320080048-004

WA100320080048-005

WA100320080048-006

AVERAGE

WA100320080048-007

WA100320080048-008

WA100320080048-009

$$
\text { AVERAGE }
$$

WA100320080048-010

WA100320080048-011

WA100320080048-012

AVERAGE

WA100320080048-013

WA100320080048-014

WA100320080048-015

AVERAGE

WA100320080048-016

WA100320080048-017

WA100320080048-018

\section{Units}

Result

Qualifier $\%$ RPD

Quantitation

Dilution Factor AVERAGE

$\mathrm{mg} / \mathrm{L}$
$\mathrm{mg} / \mathrm{L}$
$\mathrm{mg} / \mathrm{L}$
$\mathrm{mg} / \mathrm{L}$
$\mathrm{mg} / \mathrm{L}$
$\mathrm{mg} / \mathrm{L}$
$\mathrm{mg} / \mathrm{L}$
$\mathrm{mg} / \mathrm{L}$
$\mathrm{mg} / \mathrm{L}$
$\mathrm{mg} / \mathrm{L}$
$\mathrm{mg} / \mathrm{L}$
$\mathrm{mg} / \mathrm{L}$
$\mathrm{mg} / \mathrm{L}$
$\mathrm{mg} / \mathrm{L}$
$\mathrm{mg} / \mathrm{L}$
$\mathrm{mg} / \mathrm{L}$
$\mathrm{mg} / \mathrm{L}$
$\mathrm{mg} / \mathrm{L}$
$\mathrm{mg} / \mathrm{L}$
$\mathrm{mg} / \mathrm{L}$
$\mathrm{mg} / \mathrm{L}$
$\mathrm{mg} / \mathrm{L}$
$\mathrm{mg} / \mathrm{L}$
$\mathrm{mg} / \mathrm{L}$

031
029
02
0.29
0061
0060
0050
0.057
0067
006
006
006
19
18
20
19
14
14
13
14
20
19
20
20

B, D

B, D

13
25

if needed)

\section{B, D}

B, D
B,D
B,D

02

10

10

\section{B, D}

B, D

B, D

12

B, D, J, S

B, D, J, S

B, D, S

17

14

20

B, D, J, S

B, D, J, S

B, D, I, S

11
10

B, D, S

B, D, J, S

$B, D, S$

17
07

02 
$\mathrm{CH} 2 \mathrm{M}$ Hill

P O Box 1500

Ruchland, WA 99352

Attn Larry Lockrem

Phone (509)373-4711

Fax

RJLG Job No - WA100320080048 Total Chromium

Analysis Method EPA 200 8, Non-Potable Water
Tet (509) 5-45-4989 I Fax (509) 544-6010

RJ Lee Group Job No WA100320080048

Sample Collection $2 / 8 / 2008$

Samples Recerved $3 / 10 / 2008$

Report Date $7 / 15 / 2008$

Analysis/Prep Date 3/14/2008

Preparation Method EPA 1311

Chent Project Chrome VI -

GAL801937
RJ Lee Group ID

\section{Sample ID}

WA100320080048-019

WA100320080048-02

WA100320080048-02

GW pH $10-2$ TCLP Cr3+ (NR

AVERAGE

Groundwater Simulant adjusted to $\mathrm{pH}$ 11. $\mathrm{Cr} 3+$ Spike.
GW pH 11-1 TCLP Cr3+ (NR)
GW pH 11-2 TCLP Cr3+ (NR)
WA100320080048-022
GW pH 11-3 TCLP Cr3+ (NR)
(1) $00320080048-023$

WA100320080048-024

Groundwater Simulant adjusted to $\mathrm{pH} 12 \mathrm{Cr} 3+$ Spike. GW pH 12-1 TCLP Cr3+ (NR)

GW pH 12-2 TCLP Cr3+ (NR) AVERAGE

GW pH 12-3 TCLP Cr3 3 (NR)

WA100320080048-026

WA100320080048-027 AVERAGE

Groundwater Simulant adjusted to $\mathrm{pH} 10 \mathrm{Cr} 6+$ Spıke.

GW pH 10-1 TCLP Cr6+ (NR)

GW pH 10-2 TCLP Cr6+ (NI)

WA100320080048-028

WA100320080048-029

WA100320080048-030

AVERAGE

Groundwater Simulant adjusted to pH $12 \mathrm{Cr} 6+$ Spike GW pH 11-1 TCLP Cr6+ (NR)

GW $\mathrm{pH} 11-2$ TCLP Cr6+ (NR)

WA100320080048-037

GW pH 11-3 TCLP Cr6+ (NR)

WA100320080048-032

WA100320080048-033

AVERAGE

Groundwater Sımulant adjusted to $\mathrm{pH} 12 \mathrm{Cr} 6+$ Spıke GW pH 12-1 TCLP Cr6+ (NR)

GW pH 12-2 TCLP Cr6+ (NR)

GW pH 12-3 TCLP Cr6+ (NR)

WA100320080048-03-

WA100320080048-035

WA100320080048-036

AVERAGE
Units

Result Qualifier

$\%$ RPD

Quantitation

Limit

Dilution Factor (if needed)

\begin{tabular}{|c|c|c|c|c|c|}
\hline $\mathrm{mg} / \mathrm{L}$ & 18 & $B, D, J, S$ & & 20 & 100 \\
\hline $\mathrm{mg} / \mathrm{L}$ & 17 & B, D, J, S & 05 & 20 & 100 \\
\hline $\mathrm{mg} / \mathrm{L}$ & 17 & $B, D, J, S$ & 12 & 20 & 100 \\
\hline $\mathrm{mg} / \mathrm{L}$ & 17 & & & & \\
\hline $\mathrm{mg} / \mathrm{L}$ & 16 & $B, D, J, S$ & & 20 & 100 \\
\hline $\mathrm{mg} / \mathrm{L}$ & 16 & $B, D, J, S$ & 01 & 20 & 100 \\
\hline $\mathrm{mg} / \mathrm{L}$ & 16 & $B, D, J, S$ & 002 & 20 & 100 \\
\hline $\mathrm{mg} / \mathrm{L}$ & 16 & & & & \\
\hline $\mathrm{mg} / \mathrm{L}$ & 13 & $B, D, J, S$ & & 20 & 100 \\
\hline $\mathrm{mg} / \mathrm{L}$ & 15 & $B, D, J, S$ & 40 & 20 & 100 \\
\hline $\mathrm{mg} / \mathrm{L}$ & 13 & $B, D, J, S$ & 03 & 20 & 100 \\
\hline $\mathrm{mg} / \mathrm{L}$ & 14 & & & & \\
\hline $\mathrm{mg} / \mathrm{L}$ & 18 & $B, D, J, S$ & & 20 & 100 \\
\hline $\mathrm{mg} / \mathrm{L}$ & 21 & $\mathrm{~B}, \mathrm{D}, \mathrm{S}$ & 38 & 20 & 100 \\
\hline $\mathrm{mg} / \mathrm{L}$ & 18 & $B, D, J, S$ & 05 & 20 & 100 \\
\hline $\mathrm{mg} / \mathrm{L}$ & 19 & & & & \\
\hline $\mathrm{mg} / \mathrm{L}$ & 19 & B, D, J, S & & 20 & 100 \\
\hline $\mathrm{mg} / \mathrm{L}$ & 19 & B, D, J, S & 01 & 20 & 100 \\
\hline $\mathrm{mg} / \mathrm{L}$ & 19 & $B, D, J, S$ & 05 & 20 & 100 \\
\hline $\mathrm{mg} / \mathrm{L}$ & 19 & & & & \\
\hline $\mathrm{mg} / \mathrm{L}$ & 18 & B, D, J, S & & 20 & 100 \\
\hline $\mathrm{mg} / \mathrm{L}$ & 18 & $B, D, J, S$ & 03 & 20 & 100 \\
\hline $\mathrm{g} / \mathrm{L}$ & 18 & $B, D, J, S$ & 03 & 20 & 100 \\
\hline
\end{tabular}

Page 19 of 35 


\section{H2M Hull}

P O Box 1500

Rıchland, WA 99352

Attn Larry Lockrem

Phone (509)373-4711

Fax

Tel (509) 545-4989 I Fax (509) 544-6010

RJ Lee Group Job No WA100320080048

Sample Collection 2/8/2008

Samples Recerved 3/10/2008

Report Date $7 / 15 / 2008$

Analysıs/Prep Date 3/14/2008

Preparation Method EPA 1311

Chent Project Chrome VI -

GAL801937

RJLG Job No - WA100320080048 Total Chromium

Analysis Method. EPA 200.8, Non-Potable Wate

\begin{tabular}{|c|c|c|c|c|c|c|c|}
\hline Sample ID & RJ Lee Group ID & Units & Result & Qunlifier & $\%$ RPD & $\begin{array}{l}\text { Quantitation } \\
\text { Limit }\end{array}$ & $\begin{array}{l}\text { Dilution Factor } \\
\text { (if needed) }\end{array}$ \\
\hline \multicolumn{8}{|c|}{ Groundwater Simulant + Iron Sulfate adjusted to $\mathrm{pH} 10$} \\
\hline $\mathrm{GW}+\mathrm{FS}$ pH 10-1 TCLP (R) & WA100320080048-037 & $\mathrm{mg} / \mathrm{L}$ & 13 & $B, D, J, S$ & & 20 & 100 \\
\hline $\mathrm{GW}+\mathrm{FS}$ pH $10-2 \mathrm{TCLP}(\mathrm{R})$ & WA100320080048-038 & $\mathrm{mg} / \mathrm{L}$ & 12 & B, D, J, S & 16 & 20 & 100 \\
\hline \multirow[t]{2}{*}{ GW+FS $\mathrm{pH} 10-3 \mathrm{TCLP}(\mathrm{R})$} & WA100320080048-039 & $\mathrm{mg} / \mathrm{L}$ & 14 & B, D, J, S & 05 & 20 & 100 \\
\hline & AVERAGE & $\mathrm{mg} / \mathrm{L}$ & 13 & & & & \\
\hline \multicolumn{8}{|c|}{ Groundwater Sımulant + Iron Sulfate adjusted to pH 11} \\
\hline GW+FS pH 11-1 TCLP (R) & WA100320080048-040 & $\mathrm{mg} / \mathrm{L}$ & 12 & $B, D, J, S$ & & 20 & 100 \\
\hline GW+FS pH 11-2 TCLP (R) & WA100320080048-041 & $\mathrm{mg} / \mathrm{L}$ & 12 & B, D, J, S & 11 & 20 & 100 \\
\hline \multirow[t]{2}{*}{ GW+FS pH 11-3 TCLP (R) } & IVA100320080048-042 & $\mathrm{mg} / \mathrm{L}$ & 12 & $B, D, J, S$ & 03 & 20 & 100 \\
\hline & AVERAGE & mg/L. & 12 & & & & \\
\hline \multicolumn{8}{|c|}{ Groundwater Simulant + Iron Sulfate adjusted to $\mathrm{pH} 12$} \\
\hline GW+FS pH 12-1 TCLP (R) & WA100320080048-043 & $\mathrm{mg} / \mathrm{L}$ & 70 & $B, D, S$ & & 2 & 10 \\
\hline GW+FS pH 12-2 TCLP (R) & WA100320080048-044 & $\mathrm{mg} / \mathrm{L}$ & 73 & B, D, S & 09 & 2 & 10 \\
\hline \multirow[t]{2}{*}{$\mathrm{GW}+\mathrm{FS}$ pH 12-3 TCLP (R) } & WA100320080048.045 & $\mathrm{mg} / \mathrm{L}$ & 71 & B, D, S & 04 & 2 & 10 \\
\hline & AVERAGE & $\mathrm{mg} / \mathrm{L}$ & 7.1 & & & & \\
\hline
\end{tabular}

* All solid matricies reported on a dry weight basis unless otherwise noted

* All values reported without blank correction unless otherwise noted

Analyst Comments Quantitation Limut is based on the lowest point on the calıbration curve and dilution factor (where applicable)

Report Quatifiers

D-Dilution applied to sample

$H=$ Holdting times for preparation or analysts esceeded

1 - Analyle detected beloss quantitation limt

$B=$ Analyte detected in the assomated Method Blanh

$S=$ Spile Recovery oulsude accepted recovery limuts

$R=R P D$ (relatioe percent difference) ontside accepted recovery lumits

These results are submutted pursuant to RI Lee Group's current terms and conditions of sale, includung the conpany's standard watranty and lumitation of liability provistons No responsibulity or liability is assumed for the

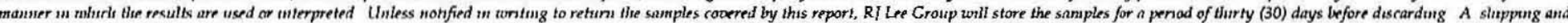
handlung fre cull be assessed for the return of any samples 
RPP-RPT-37878, Rev. 0

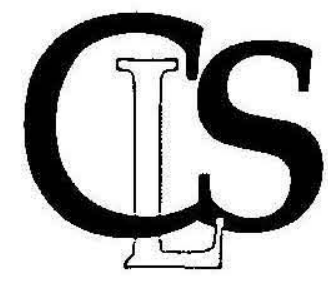

APPENDIX B

Ion Chromatography Analytical Report for Hexavalent Chromium Analysis

Prepared by:

Glynnis Anne Bowman, CHMM Operations Manager

RJ LeeGroup, Inc.

Center for Laboratory

Sciences

2710 North 201h Avenue

Pasco. WA 9930) 
CH2M Hill

P O Box 1500

Ruchland, WA 99352

Attn Larry Lockrem

Phone (509)373-4711

Fax
RJ Lee Group Job No WA100320080048

Sample Collection 2/8/2008

Samples Received 3/10/2008 Report Date $7 / 15 / 2008$

Analysis/Prep Date 3/14/2008

Preparation Method EPA 3000

$$
\text { Chent Project Chrome VI - }
$$

RJLG Job No WA100320080048 Hexavalent Chromum

Analysis Method EPA 300 0, Non-Potable Water

\section{Sumple ID \\ ID \\ $\mathrm{SS}$ pH 10-1 TCL.P Cr3+ (NR) \\ SS $\mathrm{pH}$ 10-2 ICLP Cr $3+(\mathrm{NR})$ \\ $\mathrm{SS}$ pH 10-3 TCLP Cr3+ (NR) \\ Sodium Sulfate adjusted to $\mathrm{pH} 11 \mathrm{Cr} 3+$ Spıke SS PH 11-1 TCLP Cr3+ (NR) SS pH 11-2 TCLP Cr3+ (NR) \\ SS pH 11-3 TCLP Cr3+ (NR)}

Sodium Sulfate adjusted to $\mathrm{pH} 12 . \mathrm{Cr} 3+$ Spike SS pH 12-1 TCLP Cr3+ (NR)

$S S \mathrm{pH} 12-2 \mathrm{TCLPCC} 3+(\mathrm{NR})$

$\mathrm{SS} \mathrm{pH} \mathrm{12-3} \mathrm{TCLP} \mathrm{Cr3+} \mathrm{(NR)}$

Sodium Sulfate adjusted to $\mathrm{pH} 10 \mathrm{Cr} 6+$ Spike SS pH 10-1 TCLP Cr6+ (NR)

SS pH 10-2 TCLP Cr6+ (NR)

SS pH 10-3 TCLP Cr6+ (NR)

Sodium Sulfate adjusted to $\mathrm{pH} 11 \mathrm{Cr} 6+$ Spike

$5 \mathrm{pH}$ 11-1 TCLPCr6+ (NR)

SS PH 11-2 TCL P Cr6+ (NR)

SS pH 11-3 TCLP Cr6+ (NR)

Sodium Sulfate adjusted to $\mathrm{pH} 12 . \mathrm{Cr} 6+$ Spıke

SS pl I 12-1 TCLP Cr6+ (NR)

SS pH 12-2 ICLP Cr6+ (NR)

SS pH 12-3 TCLP Cr6+ (NR)
RJ Lee Group ID

WA100320080048-001

WA100320080048-002

WA100320080048-003

AVERAGE

WA100320080048-004

WA100320080048-005

WA100320080048-006

AVERAGE

WA100320080048-007

WA100320080048-008

WA100320080048-009 AVERAGE

WA100320080048-010

WA100320080048-011

WA $100320080048-012$

$$
\text { AVERAGE }
$$

WA100320080048-013

WA100320080048-014

WA100320080048-015

$$
\text { AVERAGE }
$$

WA100320080048-016

WA100320080048-017

WA100320080048-018 AVERAGE

\section{Unils}

Result

Qualifier

$\%$ RPD

Quantitation Limit

Dilution Factor

$\begin{array}{cccc}\mathrm{mg} / \mathrm{L} & 0058 & 13 & 00025 \\ \mathrm{mg} / \mathrm{L} & 0061 & 09 & 00025 \\ \mathrm{mg} / \mathrm{L} & 006 & & \\ \mathrm{mg} / \mathrm{L} & 0060 & & 00025 \\ \mathrm{mg} / \mathrm{L} & 00033 & 07 & 00025 \\ \mathrm{mg} / \mathrm{L} & 00032 & 11 & 00025 \\ \mathrm{mg} / \mathrm{L} & 00032 & & \\ \mathrm{mg} / \mathrm{L} & 00032 & & \\ \mathrm{mg} / \mathrm{L} & 00073 & 05 & 00025 \\ \mathrm{mg} / \mathrm{L} & 00071 & 25 & 00025 \\ \mathrm{mg} / \mathrm{L} & 00066 & & \end{array}$

$\mathrm{mg} / \mathrm{L} \quad 00070$

$\mathrm{mg} / \mathrm{L} \quad 17$

$\mathrm{mg} / \mathrm{L} \quad 18$

$\mathrm{mg} / \mathrm{L} \quad 18$

$\mathrm{mg} / \mathrm{L} \quad 18$

$\mathrm{mg} / \mathrm{L} \quad 15$

$\mathrm{mg} / \mathrm{L} \quad 15$

$\mathrm{mg} / \mathrm{L} \quad 14$

$\mathrm{mg} / \mathrm{L} \quad 15$

$\mathrm{mg} / \mathrm{L} \quad 19$

$\mathrm{mg} / \mathrm{L} \quad 20$

$\mathrm{mg} / \mathrm{L} \quad 20$

$\mathrm{mg} / \mathrm{L} \quad 20$
100

$\begin{array}{lll}13 & 025 & 100 \\ 08 & 025 & 100\end{array}$

D 025

$001-025$

$\begin{array}{llll}\mathrm{D} & & 025 & 100 \\ \mathrm{D} & 14 & 025 & 100 \\ \mathrm{D} & 07 & 025 & 100\end{array}$


$\mathrm{CH} 2 \mathrm{M} \mathrm{H}$ il

P O Box 1500

Ruchland, WA 99352

Attn Larry Lockrem

Phone (509)373-4711

Fax
RI Lee Group Job No WA100320080048 Sample Collecton $2 / 8 / 2008$ Samples Received 3/10/2008 Report Date $7 / 15 / 2008$

Analysis/Prep Date 3/14/2008

Preparation Method EPA 3000

Client Project Chrome VI -

RJLG Job No WA100320080048 Hexavalent Chromuum

Analysis Method EPA 300 0, Non-Potable Water

\section{Sample ID \\ RJ Lee Group ID}

GW pH 10-1 TCLP Cr3+ (NR)

GW pH 10-2 TCLP Cr $3+(\mathrm{NR})$

GW pH 10-3 TCLP Cr3+ (NR)

WA100320080048-02

WA100320080048-021

AVERAGE

Groundwater Simulant adjusted to $\mathrm{pH} 11 \mathrm{Cr} 3+$ Spike GW pH 11-1 TCLP Cr3+ (NR)

GW pH 11-2 TCLP Cr3+ (NR)

WA100320080048-022

GW pH 11-3 TCLP Cr3+ (NR)

WA100320080048-023

WA100320080048-024

AVERAGE

Groundwater Simulant adjusted to $\mathrm{pH} 12 \mathrm{Cr} 3+$ Spike GW pH 12-1 TCLP Cr3+ (NR)

WA100320080048-025

GW pH 12-2 TCLP Cr3+ (NR)

WA100320080048-026

GW pH 12-3 TCLP Cr3+ (NR) AVERAGE

Groundwater Simulant adjusted to $\mathrm{pH} 10 \mathrm{Cr} 6+$ Spike GW pH 10-1 TCLP Cr6+ (NR)

GW pH 10-2 TCLP Cr6+ (NR)

WA100320080048-028 GW pH 10-3 TCLP Cr6+ (NR)

WA100320080018-030

$$
\text { AVERAGE }
$$

Groundwater Simulant adjusted to $\mathrm{pH} 11 \mathrm{Cr} 6+$ Spıke
GW pH 11-1 TCLP Cr6+ (NR)
GW pH 11-2 TCLP Cr6+ (NR)
NA100320080048-031
GW pH 11-3 TCLP Cr6+ (NR)
WA100320080048-032
WA100320080048-033

$$
\text { AVERAGE }
$$

Groundwater Simulant adjusted to $\mathrm{pH} 12 \mathrm{Cr} 6+$ Spike

GW pH 12-1 TCLP Cr6+ (NR)

GW pH 12-2 TCLP Cr6+ (NR)

GW pH 12-3 TCLP Cr6+ (NR)

WA100320080048-034

WA100320080048-035

WA100320080048-036

AVERAGE

\section{Units}

Result

Qualifier

$\%$ RPD

Quantitation

Limit

Dilution Factor

$\mathrm{mg} / \mathrm{L} \quad 16025$

$\mathrm{mg} / \mathrm{L} \quad 17$

$\mathrm{mg} / \mathrm{L} \quad 17$

$\mathrm{mg} / \mathrm{L} \quad 17$

100

$\mathrm{mg} / \mathrm{L}$

$\mathrm{mg} / \mathrm{L} \quad 30$

$\mathrm{mg} / \mathrm{L} \quad 32$

$\mathrm{mg} / \mathrm{L} \quad 33$

$\mathrm{mg} / \mathrm{L} \quad 32$

$\mathrm{mg} / \mathrm{L} \quad 27$

$\mathrm{mg} / \mathrm{L} \quad 29$

$\mathrm{mg} / \mathrm{L} \quad 26$

$\mathrm{mg} / \mathrm{L} \quad 27$

$\mathrm{mg} / \mathrm{L} \quad 16$

$\mathrm{mg} / \mathrm{L} \quad 15$

$\mathrm{mg} / \mathrm{L} \quad 16$

$\mathrm{mg} / \mathrm{L} \quad 16$

$\mathrm{mg} / \mathrm{L} \quad 16$

$\mathrm{mg} / \mathrm{L} \quad 16$

$\mathrm{mg} / \mathrm{L} \quad 15$

$\mathrm{mg} / \mathrm{L} \quad 16$

$\mathrm{mg} / \mathrm{L} \quad 16$

$\mathrm{mg} / \mathrm{L} \quad 17$

$\mathrm{mg} / \mathrm{L} \quad 15$ 


\section{『S}

$\mathrm{CH} 2 \mathrm{M}$ Hill

P O Box 1500

Ruchland, WA 99352

Attn Larry Lockrem

Phone (509)373-4711

Fax

RJ LeeGroup, Inc. ICenter for Laboratory Sciences

2710 North 20th Avenue Pasco IVA 9930

Tel (509) 545-4989 I Fax (509) 541-6010

RJ Lee Group Job No WA100320080048

Sample Collection $2 / 8 / 2008$

Samples Recerved 3/10/2008 Report Date $7 / 15 / 2008$

Analysss/Prep Date 3/14/2008 Preparation Method LPA 3000

Client Project Chrome VI -

GAL801937

RILG Job No WA100320080048 Hexavalent Chromium

Analysis Method EPA 300 0, Non-Potable Wate

\section{Sample ID}

RJ Lee Group ID

Units

Result Qualifier \% RPD

Quantitation

Dilution Factor

Groundwater Simulant, $\mathrm{Cr}^{6+}$ spike + Iron Sulfate adjusted to $\mathrm{pH} 10$

GW+FS pH 10-1 TCLP (R)

GW+FS pH 10-2 TCLP (R) WA100320080048-038

GW+FS pH 10-3 TCLP (R) WA100320080048-039

AVERAGE

Groundwater Simulant, $\mathrm{Cr}^{6+}$ spike + Iron Sulfate adjusted to $\mathrm{pH} 11$
GW+FS pH 11-1 TCLP (R)
GW+FS pH 11-2 TCL.P (R)
WA100320080048-040
GW+FS pH 11-3 TCLP (R)
WA100320080048-04
WA $100320080048-042$
AVERAGE

Groundwater Simulant, $\mathrm{Cr}^{\circ{ }^{\circ}}$ spıke + Iron Sulfate adjusted to $\mathrm{pH} 12$
$\mathrm{GW}+\mathrm{FS}$ pH 12-1 TCLP (R)
WA100320080048-043
$\mathrm{GW}+\mathrm{FS}$ pH 12-2'ICLP (R)
WA100320080048-04
WA100320080048-045

$\begin{array}{cccccc}\mathrm{mg} / \mathrm{L} & 018 & \mathrm{D} & & 025 & 100 \\ \mathrm{mg} / \mathrm{L} & 017 & \mathrm{D} & 06 & 025 & 100 \\ \mathrm{mg} / \mathrm{L} & 018 & \mathrm{D} & 002 & 025 & 100 \\ \mathrm{mg} / \mathrm{L} & 018 & & & & \\ & & & & & \\ \mathrm{mg} / \mathrm{L} & 026 & \mathrm{D} & & 025 & 100 \\ \mathrm{mg} / \mathrm{L} & 025 & \mathrm{D} & 060 & 025 & 100 \\ \mathrm{mg} / \mathrm{L} & 025 & \mathrm{D} & 06 & 025 & 100\end{array}$

$$
\text { AVERAGE }
$$

$\mathrm{mg} / \mathrm{L} \quad 025$

$\begin{array}{cccccc}\mathrm{mg} / \mathrm{L} & 024 & \mathrm{D} & & 025 & 100 \\ \mathrm{mg} / \mathrm{L} & 034 & \mathrm{D} & 90 & 025 & 100 \\ \mathrm{mg} / \mathrm{L} & 028 & \mathrm{D} & 41 & 025 & 100 \\ \mathrm{mg} / \mathrm{L} & 029 & & & & \end{array}$

* All solid matncies reported on a dry weight basis unless otherwese noted

* All values reported without blank correction unless otherwise noted

Analyst Comments Quantitation Limut is based on the lowest point on the calibration curve and dulution factor (where applicable)

\section{Report Qualifiers}

De Duluttom appited to sample

$H=$ Holding tumes for preparation or analysis exceeded

$1=$ Analyte detcted belos quartutation lamts

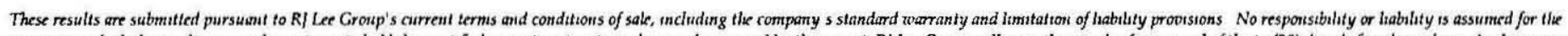

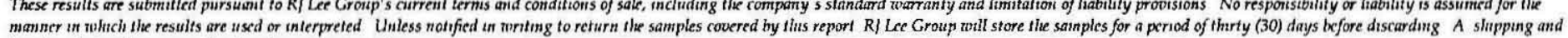
handiung fee will be assessed for thic rrturn of any samples 
RPP-RPT-37878, Rev 0

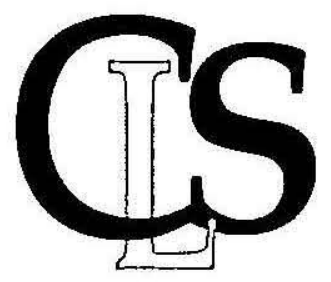

\section{APPENDIX C}

Quality Assurance Reports

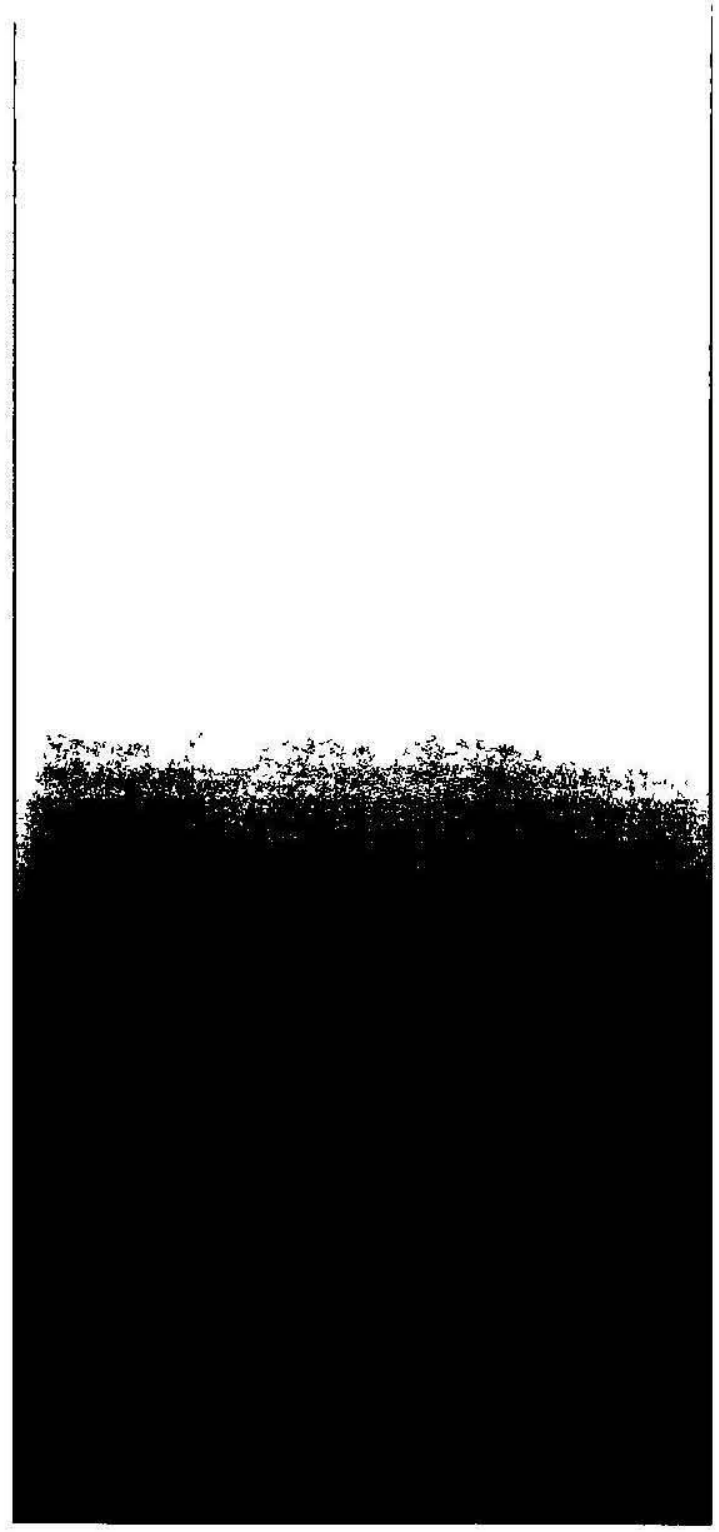




\section{Appendix C: Quality Assurance Report}

\section{Recovery of Total Chromium for Samples 001 through 009 (ICP-MS Analysis)}

The recovery of total chromium falled to meet expectations for the sodium sulfate samples (001-009) fortified to $100 \mathrm{ppm}$ chromium III. Recovery of chromıum following TCLP extraction of these samples was expected to be at least as high as the recovery for the chromium III fortified groundwater brine samples (019-027).

The parent sodium sulfate solutions that resulted in 001 through 009 consisted of deionized water and ACS grade $\mathrm{Na}_{2} \mathrm{SO}_{4}$ and the single element trivalent chromium standard (10,000 ppm). No other materials were added to the solution prior to evaporatıon Following cvaporation, the samples were treated as discussed in the report for TCLP extraction-no other materials were added to the evaporites other than the extraction fluid. The resulting leachate exhibited no color and no precipitates

The RJ Lee Group, CLS staff has researched these anomalies and have not determıned an explanation for the ICP-MS results The following considerations were taken into account

\section{- Fallure of the fortification delıvery mechanısm:}

Prior to the on start of fortification, the bottle of the single element trivalent chromium standard $(10,000$ ppm) was unopened and contained a nomınal volume of $10 \mathrm{ml}$ Following the delivery of the three $3 \mathrm{ml}$ spikes the volume remaining in the standard bottle was approximately $1 \mathrm{ml}$. No other analytıcal work requiring fortıfication with a trivalent chromium standard solution occurred during the time of the preparatory work for the RPP-PLAN-35958

- Erroneous chromium concentration reported on the label of the standard:

The remaining portion of this standard was analyzed on the ICP-MS on June 19, 2008 and the results from three sub-samples yielded an average total chromium concentration of $1.04 \times 10^{4} \mathrm{ppm}$

- Failure of the ICP-MS sample induction mechanism to take up the appropriate volume of subsample If the instrument's peristaltıc pump fails to deliver the appropriate volume of subsample, the concentration reported on the instrument data sheets can be either greatly exaggerated or undervalued. 
These samples were run again via ICP-MS with resultıng sımılar concentratıons Three samples, one from each $\mathrm{pH}$ range were also checked with the ICP-AES and the recovery of total chromium was of the same magnitude as the ICP-MS data

- Farlure of the ICP-MS to recover total chromium.

Samples 001 through 009 were analyzed in the same batch run as samples 010 through 018 (fortıfied to $100 \mathrm{ppm}$ hexavalent chromıum). The total chromium recovery for samples 010 through 018 is not in question and the corresponding hexavalent chromıum (IC) results compare very well with the ICP-MS data for these samples

The batch quality control samples (calıbratıon verıfication, calıbratıon blank, detection lımit, laboratory control standard, and laboratory fortified blank) analyzed with samples 001 through 009 in the ICP-MS Instrument run are all within the acceptable toleration range of $+/-25 \%$ recovery.

- Fractıonal crystallization during evaporation resultıng in a non-homogeneous evaporite.

Prior to TCLP leachıng, the samples were manually crushed in order to generate a homogenous material for leaching. A portion of the crushed sample was removed to test for TCLP extraction fluid determination. The remainder of the sample (minus a portion that adhered to the beaker walls) was subjected to leaching

In order to rule this mechanism out, the TCLP procedure and ICP-MS analysis would have to be repeated and there is insufficient material remainıng to accomplısh thıs.

\section{Discussion of Analytical Report Qualifiers}

\section{Inductively Coupled Plasma-Mass Spectroscopy (Total Chromium Concentration)}

\section{- ICP-MS Data B Qualıfiers}

The reagent blanks prepared and analyzed within the instrument run for the total chromium concentration analysis were slightly above the level of the detection limit sample ( $002 \mathrm{ppm}$ chromım). Therefore, the sample data is presented with a B qualıfier This data was not blank corrected With the exception of samples 001 through 009 discussed earlier as presenting problematic data, the effect of 
blank correction at the level of $002 \mathrm{ppm}$ would have no effect on the high chromıum concentrations of the remaining 36 samples

\section{- ICP-MS Data S Qualıfiers}

The ICP-MS quality control analyses (ICV, DL LCS, LCSD and CCVs) were within the tolerance limits of $+/-25 \%$ with the exception of the analytical batch sample spikes

Samples $-013,-022,-025,-034,-040$ and -043 exhibited spikes of greater than $145 \%$ recovery It is possible that the spike concentration introduced to the sample split was $05 \mathrm{ppm}$ chromium as opposed to $005 \mathrm{ppm}$ chromıum

All other sample spıkes exhibit a negatıve recovery as compared to the sample that the spike was split from It is likely that the spıke concentration of $005 \mathrm{ppm}$ was lost within the very high chromıum concentrations of the samples ( 7.1 through $20 \mathrm{ppm}$ ). The allowable statistical variation around the sample concentration at these values is such that $005 \mathrm{ppm}$ addition of chromım is not statıstically viable. The spike concentration for this set of samples was established such that if the sequestering of chromıum had been effective, a $005 \mathrm{ppm}$ chromıum spike would have been recoverable.

\section{Ion Chromatography (Hexavalent Chromium Concentration)}

There were no data qualifiers applied to the hexavalent chromım laboratory report. All of the IC quality control analyses (ICV, DL, LCS, and CCVs) were within the tolerance limits of $+/-25 \%$. All of the spıke concentration recoveries were withın the lımıts of $+/-25 \%$ 


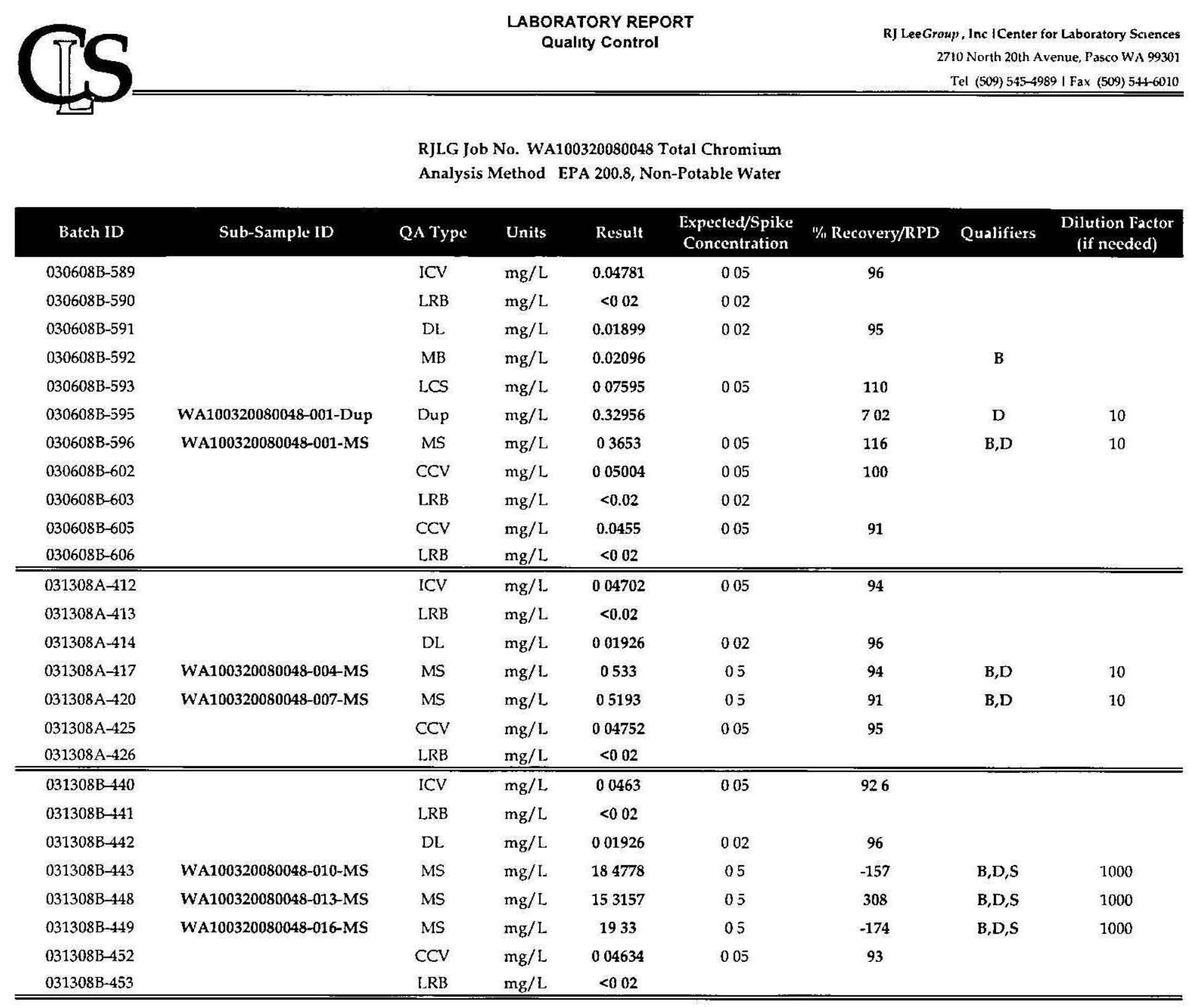




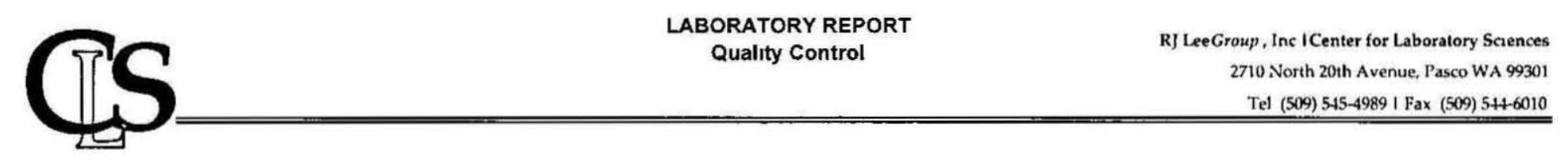

RJLG Job No.: WA100320080048 Total Chromium Analysıs Method: EPA 200 8, Non-Potable Water

\begin{tabular}{|c|c|c|c|c|c|c|c|c|}
\hline Batch ID & Sub-Sample ID & QA Type & Units & Result & $\begin{array}{l}\text { Expected/Spike } \\
\text { Concentration }\end{array}$ & $\%$ Recovery/RPD & Qualifiers & $\begin{array}{l}\text { Dilution Factor } \\
\text { (if needed) }\end{array}$ \\
\hline 031308D-483 & & $\mathrm{ICV}$ & $\mathrm{mg} / \mathrm{L}$ & 046342 & 05 & 93 & & \\
\hline 031308D-484 & & LRB & $\mathrm{mg} / \mathrm{L}$ & $<0.02$ & & & & \\
\hline 031308D-485 & & DL & $\mathrm{mg} / \mathrm{L}$ & 020158 & 02 & 101 & & \\
\hline 031308D-486 & & LCS & $\mathrm{mg} / \mathrm{L}$ & 0.0777 & 005 & 114 & & \\
\hline $031308 \mathrm{D}-487$ & & LCSD & $\mathrm{mg} / \mathrm{L}$ & 007467 & 005 & 108 & & \\
\hline $031308 \mathrm{D}-488$ & & $\mathrm{MB}$ & $\mathrm{mg} / \mathrm{L}$ & 002054 & & & $\mathbf{B}$ & \\
\hline $031308 \mathrm{D}-490$ & WA100320080048-019-MS & MS & $\mathrm{mg} / \mathrm{L}$ & 16.8493 & 005 & -1585 & $\mathrm{~B}, \mathrm{D}, \mathrm{S}$ & 100 \\
\hline $031308 \mathrm{D}-494$ & WA100320080048-022-Dup & Dup & $\mathrm{mg} / \mathrm{L}$ & 16.85771 & & 609 & $\mathrm{D}$ & 100 \\
\hline $031308 \mathrm{D}-495$ & WA100320080048-022-MS & MS & $\mathrm{mg} / \mathrm{L}$ & 16005 & 005 & 287 & $B, D, S$ & 100 \\
\hline 031308D-496 & & $\mathrm{CCV}$ & $\mathrm{mg} / \mathrm{L}$ & 0.47048 & 05 & 94 & & \\
\hline 031308D-497 & & LRB & $\mathrm{mg} / \mathrm{L}$ & $<0.02$ & & & & \\
\hline 031308D-501 & WA100320080048-025-MS & MS & $\mathrm{mg} / \mathrm{L}$ & 13.108 & 005 & 258 & $\mathrm{~B}, \mathrm{D}, \mathrm{S}$ & 100 \\
\hline 031308D-505 & WA100320080048-028-Dup & Dup & $\mathrm{mg} / \mathrm{L}$ & 1871458 & & 340 & D & 100 \\
\hline 031308D-506 & WA100320080048-028-MS & MS & $\mathrm{mg} / \mathrm{L}$ & 180838 & 005 & -11 & $\mathrm{~B}, \mathrm{D}, \mathrm{S}$ & 100 \\
\hline 031308D-508 & & $\mathrm{CCV}$ & $\mathrm{mg} / \mathrm{L}$ & 04697 & 05 & 94 & & \\
\hline 031308D-509 & & LRB & $\mathrm{mg} / \mathrm{L}$ & $<002$ & & & & \\
\hline 031308D-512 & WA100320080048-031-MS & MS & $\mathrm{mg} / \mathrm{L}$ & 188528 & 005 & -192 & $\mathrm{~B}, \mathrm{D}, \mathrm{S}$ & 100 \\
\hline 031308D-516 & WA100320080048-034-MS & MS & $\mathrm{mg} / \mathrm{L}$ & 18.1052 & 005 & 301 & $\mathrm{~B}, \mathrm{D}, \mathrm{S}$ & 100 \\
\hline 031308D-520 & & $\mathrm{CCV}$ & $\mathrm{mg} / \mathrm{L}$ & 0.48931 & 05 & 98 & & \\
\hline 031308D-521 & & LRB & $\mathrm{mg} / \mathrm{L}$ & $<0.02$ & & & & \\
\hline 031308D-505 & WA100320080048-037-Dup & Dup & $\mathrm{mg} / \mathrm{L}$ & 12.8336 & & 3.34 & $\mathrm{D}$ & 100 \\
\hline 031308D-523 & WA100320080048-037-MS & MS & $\mathrm{mg} / \mathrm{L}$ & 13.1984 & 005 & -157 & $\mathrm{~B}, \mathrm{D}, \mathrm{S}$ & 100 \\
\hline 031308D-527 & WA100320080048-040-MS & MS & $\mathrm{mg} / \mathrm{L}$ & 1211802 & 005 & 145 & $\mathrm{~B}, \mathrm{D}, \mathrm{S}$ & 100 \\
\hline 031308D-532 & & $\mathrm{CCV}$ & $\mathrm{mg} / \mathrm{L}$ & 0.49277 & 05 & 99 & & \\
\hline 031308D-533 & & LRB & $\mathrm{mg} / \mathrm{L}$ & $<002$ & & & & \\
\hline 031308D-578 & WA100320080048-043-MS & MS & $\mathrm{mg} / \mathrm{L}$ & 7.38941 & 005 & 769 & $B, D, S$ & 10 \\
\hline
\end{tabular}




LABORATORY REPORT
Quality Control $\begin{array}{r}\text { RJ LeeGroup, Inc ICenter for Laboratory Sciences } \\ 2710 \text { North } 20 \text { th Avenue, Pasco WA } 99301 \\ \text { Tel } \\ (509) 545-4989 \text { I Fax } \\ (509) \text { 5.4-6010 }\end{array}$

RJLG Job No.. WA100320080048 Total Chromium Analysis Method. EPA 200.8, Non-Potable Water

\begin{tabular}{cccccccc}
\hline Batch ID & Sub-Sample ID & QA Type & Units & Result & $\begin{array}{c}\text { Expected/Spike } \\
\text { Concentration }\end{array}$ & $\begin{array}{c}\text { "/ Recovery/RPD } \\
\text { Qualifiers }\end{array} \begin{array}{c}\text { Dilution Factor } \\
\text { (if needed) }\end{array}$ \\
\hline 031308D-580 & CCV & $\mathrm{mg} / \mathrm{L}$ & 04917 & 05 & 98 \\
$031308 \mathrm{D}-581$ & $\mathrm{LRB}$ & $\mathrm{mg} / \mathrm{L}$ & $<0.02$ & & 96 \\
$031308 \mathrm{D}-583$ & $\mathrm{CCV}$ & $\mathrm{mg} / \mathrm{L}$ & 0.4807 & 05 & \\
$031308 \mathrm{D}-584$ & $\mathrm{LRB}$ & $\mathrm{mg} / \mathrm{L}$ & $<002$ & & \\
\hline \hline
\end{tabular}

* All solid matncies reported on a dry weight basis unless otherwise noted Analyst Comments

\section{Report Qualifiers}

$D=$ Dilution appticd to sample

$H=$ Holdung tunes for preparation or analysis exceeded

$L=$ Sample condition at receipt out of complance unth method defined conditons

$B=$ Analyte detected wi the ossocated Acethod Blank

$S=$ Spike Recovery outsade accepted recovery limuts

$R=R P D$ (rilative percent difference) outside accepted recovery lamits

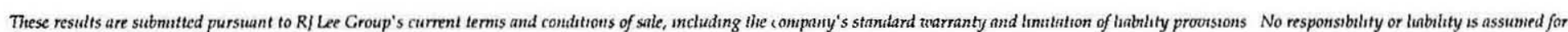

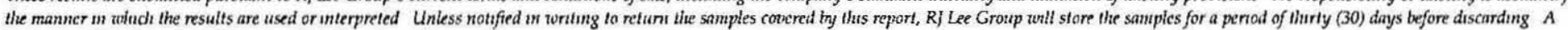

shapping and handing fee unll be assessed for the returm of any samples 
LABORATORY REPORT

RJLG Job No : WA100320080048 Hexavalent Chromium Analysis Method. EPA 300.0, Non-Potable Water

\begin{tabular}{|c|c|c|c|c|c|c|c|c|}
\hline \multicolumn{9}{|c|}{$\begin{array}{l}\text { RJLG Job No: WA100320080048 Hexavalent Chromium } \\
\text { Analysis Method· EPA } 300.0 \text {, Non-Potable Water }\end{array}$} \\
\hline Batch ID & Sub-Sample ID & QА Type & Units & Result & $\begin{array}{l}\text { Expected/Spike } \\
\text { Concentration }\end{array}$ & $1 \%$ Recovery & Qualifier & $\begin{array}{l}\text { Dilution Factor } \\
\text { (if needed) }\end{array}$ \\
\hline $\mathrm{X} 031208 \mathrm{~A}-004$ & & LRB & $\mathrm{mg} / \mathrm{L}$ & $<00025$ & & & & \\
\hline X031208A-005 & & ICV & $\mathrm{mg} / \mathrm{L}$ & 0.095253 & 01 & 95 & & \\
\hline$X 031208 \mathrm{~A}-007$ & & LCS & $\mathrm{mg} / \mathrm{L}$ & 0009228 & 001 & 92 & & \\
\hline X031208A-010 & & DL & $\mathrm{mg} / \mathrm{L}$ & 0001982 & 00025 & 79 & & \\
\hline $\mathrm{X} 031208 \mathrm{~A}-020$ & & $\mathrm{CCV}$ & $\mathrm{mg} / \mathrm{L}$ & 0093454 & 01 & 93 & & \\
\hline $\mathrm{X} 031208 \mathrm{~A}-021$ & & LRB & $\mathrm{mg} / \mathrm{L}$ & $<00025$ & & & & \\
\hline $\mathrm{X} 031208 \mathrm{~A}-030$ & WA100320080048-001-MS & MS & $\mathrm{mg} / \mathrm{L}$ & 0106054 & 005 & 96 & & \\
\hline $\mathrm{X} 031208 \mathrm{~A}-031$ & WA100320080048-002-MS & MS & $\mathrm{mg} / \mathrm{L}$ & 0107526 & 005 & 93 & & \\
\hline$X 031208 \mathrm{~A}-032$ & WA100320080048-003-MS & MS & $\mathrm{mg} / \mathrm{L}$ & 0106949 & 005 & 94 & & \\
\hline X031208A-033 & & $\mathrm{CCV}$ & $\mathrm{mg} / \mathrm{L}$ & 0.097597 & 01 & 98 & & \\
\hline $\mathrm{X} 031208 \mathrm{~A}-034$ & & LRB & $\mathrm{mg} / \mathrm{L}$ & $<00025$ & & & & \\
\hline X031208A-035 & WA100320080048-013-MS & MS & $\mathrm{mg} / \mathrm{L}$ & 18.754091 & 5 & 85 & D & 100 \\
\hline $\mathrm{X} 031208 \mathrm{~A}-042$ & & $\mathrm{CCV}$ & $\mathrm{mg} / \mathrm{L}$ & 0.094846 & 01 & 95 & & \\
\hline$\times 031208 \mathrm{~A}-043$ & & L.RB & $\mathrm{mg} / \mathrm{L}$ & $<00025$ & & & & \\
\hline X031308A-005 & & LRB & $\mathrm{mg} / \mathrm{L}$ & $<00025$ & & & & \\
\hline$X 031308 \mathrm{~A}-006$ & & $\mathrm{ICV}$ & $\mathrm{mg} / \mathrm{L}$ & 0.107451 & 01 & 107 & & \\
\hline X031308A-011 & & $\mathrm{CCV}$ & $\mathrm{mg} / \mathrm{L}$ & 0109339 & 01 & 109 & & \\
\hline X031308A-012 & & LRB & $\mathrm{mg} / \mathrm{L}$ & $<00025$ & & & & \\
\hline X051608A-001 & & ICV & $\mathrm{mg} / \mathrm{L}$ & 0.097052 & 01 & 97 & & \\
\hline $\mathrm{X} 051608 \mathrm{~A}-002$ & & DL & $\mathrm{mg} / \mathrm{L}$ & 0002188 & 00025 & 88 & & \\
\hline$X 051608 \mathrm{~A}-003$ & & LCS & $\mathrm{mg} / \mathrm{L}$ & 0097861 & 01 & 98 & & \\
\hline X051608A-004 & & LCSD & $\mathrm{mg} / \mathrm{L}$ & 0 09928 & 01 & 99 & & \\
\hline$\times 051608 \mathrm{~A}-005$ & & LRB & $\mathrm{mg} / \mathrm{L}$ & $<00025$ & & & & \\
\hline X051608A-019 & & $\mathrm{CCV}$ & $\mathrm{mg} / \mathrm{L}$ & 0.093966 & 01 & 94 & & \\
\hline $\mathrm{X} 051608 \mathrm{~A}-020$ & & LRB & $\mathrm{mg} / \mathrm{L}$ & $<00025$ & & & & \\
\hline X051608A-030 & & $\mathrm{CCV}$ & $\mathrm{mg} / \mathrm{L}$ & 0097878 & 01 & 98 & & \\
\hline $\mathrm{X} 051608 \mathrm{~A}-031$ & & LRB & $\mathrm{mg} / \mathrm{L}$ & $<00025$ & & & & \\
\hline
\end{tabular}




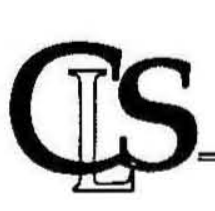

LABORATORY REPORT

Quality Control

RJ LeeGroup, Inc ICenter for Laboratory Sciences 2710 North 20th Avenue, Pasco WA 99301 Tel (509) 545-4989 I Fax (509) 54+6010

\section{RJLG Job No.. WA100320080048 Hexavalent Chromium}

Analysis Method EPA 300.0, Non-Potable Water

\section{Batch ID}

Sub-Sample ID

QA Type

Units

Result

Expected/Spike

$\%$ Recovery

Qualifier

Dilution Factor
(if needed)

* All solid matricies reported on a dry weight basis unless otheruzse noted

Analyst Comments

\section{Report Qualifiers}

$D *$ Dilution appled to sample

$H=$ Holdting tumes for preparation or analysis exceeded

$L=$ Sample conditton at recetpt out of conplance unth method defined condittons
$B=$ Analyte detected in the assocated Method Blant

$S=$ Sple Recorery outside accepted reconery limuts

$R=R P D$ (relative percent difference) outside accepted reconery limts

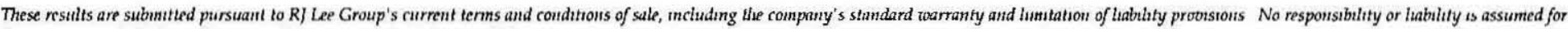

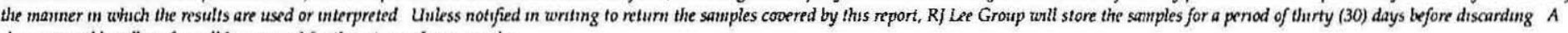
slatpping and handing foe unll be assessed for the return of any samples 


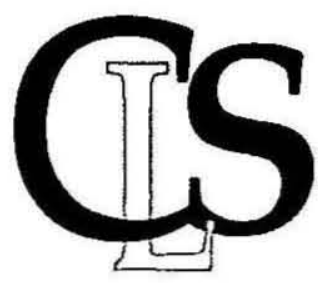

\title{
APPENDIX D
}

\author{
Chain of Custody for \\ Simulated Groundwater \\ Brine Samples Relinquished \\ to $222 \mathrm{~S}$
}


RPP-RPT-37878, Rev. 0

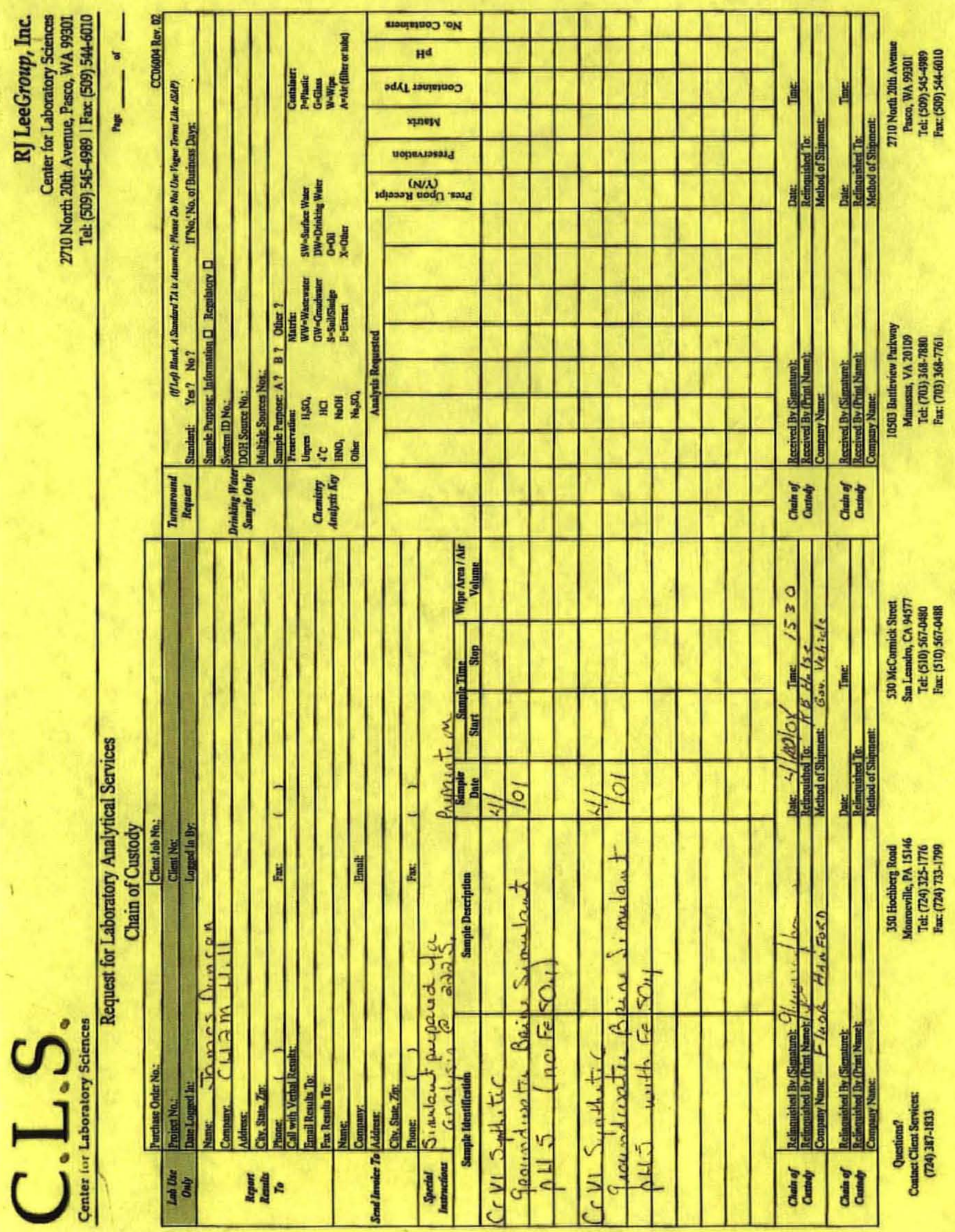

